Nevada

Environmental

Restoration

Project

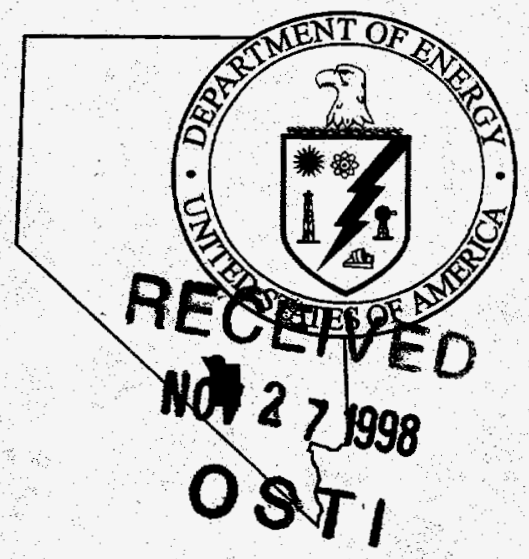

\title{
Closure Report for Housekeeping Category Corrective Action Unit 347 Nevada Test Site
}

Controlled Copy No.

Revision: 0 DISTRBUTION OF THIS DOCUMENT IS UNLMTREY

January 1998

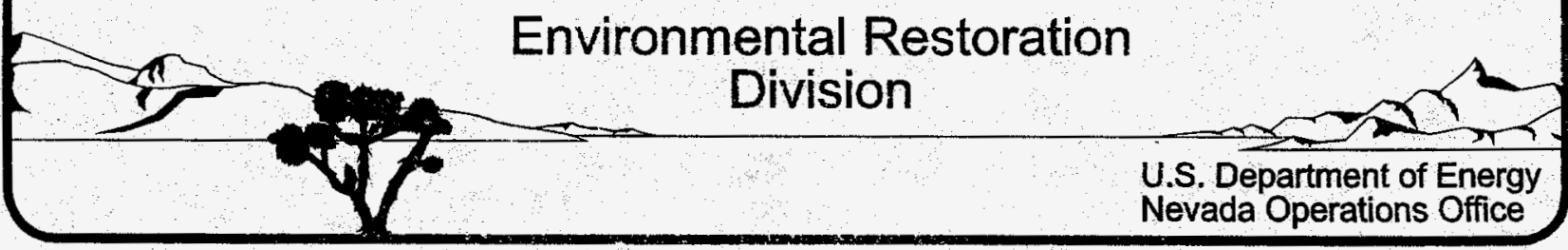




\section{DISCLAMMER}

This report was prepared as an account of work sponsored by an agency of the United States Government. Neither the United States Government aor any agency thereof, nor any of their employees, makes any warranty, express or implied, or assumes any legal liability or responsibility for the accuracy, completeness, or usefulness of any information, apparatus, product, or process disclosed, or represents that its use would not infringe privately owned rights. Refereace berein to any specific commercial product, process, or service by trade name, trademark thanufacturer, or otherwise does not necessarily constitute or imply its endorsement. recommendation, or favoring by the United States Governmeat or any agency thereof. The views and opinions of authors expressed berein do not pecessarily state or reflect those of the. United States Government or any agency thereof. 


\section{DISCLAIMER}

Portions of this document may be illegible in electronic image products. Images are produced from the best available original document. 


\title{
CLOSURE REPORT FOR HOUSEKEEPING CATEGORY CORRECTIVE ACTION UNIT 347 NEVADA TEST SITE
}

\author{
Prepared for \\ U.S. Department of Energy \\ Nevada Operations Office \\ Under Contract No. DE-AC08-96NV11718
}

Controlled Copy No.:

Revision: 0

\author{
Prepared by \\ Bechtel Nevada \\ Environmental Restoration
}

January 1998 


\section{FFACO HOUSEKEEPING CATEGORY CORRECTIVE ACTION UNIT 347}

\begin{tabular}{|c|c|c|}
\hline 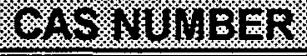 & 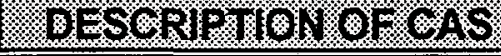 & S.8.868 \\
\hline $05-22-01$ & $\begin{array}{l}\text { Drums, gas cans, gas tank \& } \\
\text { battery }\end{array}$ & $\begin{array}{l}\text { Materials were removed. No } \\
\text { further action required. }\end{array}$ \\
\hline 05-22-06 & 55-gallon non-empty drum & $\begin{array}{l}\text { Item had previously been } \\
\text { removed. No further action } \\
\text { required. }\end{array}$ \\
\hline $05-22-13$ & Drums \& battery & $\begin{array}{l}\text { Materials had previously been } \\
\text { removed. No further action } \\
\text { required. }\end{array}$ \\
\hline $05-22-15$ & (1) Drum & $\begin{array}{l}\text { Item had previously been } \\
\text { removed. No further action } \\
\text { required. }\end{array}$ \\
\hline $05-22-17$ & (1) Drum & $\begin{array}{l}\text { Item and additional materials } \\
\text { were removed. No further action } \\
\text { required. }\end{array}$ \\
\hline $05-22-20$ & (1) Drum & $\begin{array}{l}\text { Item had previously been } \\
\text { removed. No further action } \\
\text { required. }\end{array}$ \\
\hline $05-22-22$ & (1) Drum & $\begin{array}{l}\text { Item and additional materials } \\
\text { were removed. No further action } \\
\text { required. }\end{array}$ \\
\hline $05-22-23$ & (1) 30-gal. drum & $\begin{array}{l}\text { Item and additional materials } \\
\text { were removed. No further action } \\
\text { required. }\end{array}$ \\
\hline $05-22-24$ & (1) Crushed empty drum & $\begin{array}{l}\text { Item and additional materials } \\
\text { were removed. No further action } \\
\text { required. }\end{array}$ \\
\hline $05-22-39$ & (1) 5-gal. bucket & $\begin{array}{l}\text { Item had previously been } \\
\text { removed. No further action } \\
\text { required. }\end{array}$ \\
\hline $05-24-06$ & Battery, tank, cistern & $\begin{array}{l}\text { No cisterns were found, but } \\
\text { other identified materials and } \\
\text { debris were removed. No further } \\
\text { action required. }\end{array}$ \\
\hline $05-99-06$ & Decon boots; caustic lime & $\begin{array}{l}\text { Materials were removed. } \\
\text { "Caustic lime" was actually } \\
\text { unexpended smoke pot product; } \\
\text { this was treated at the A-11 } \\
\text { EODU. No further action } \\
\text { required. }\end{array}$ \\
\hline
\end{tabular}




\section{FFACO HOUSEKEEPING CATEGORY CORRECTIVE ACTION UNIT 347}

\begin{tabular}{|c|l|l|l|}
\hline \hline $11-22-01$ & (5) empty 55-gal. drums & $\begin{array}{l}\text { Materials had previously been } \\
\text { removed. No further action } \\
\text { required. }\end{array}$ \\
\hline $11-22-02$ & (6) empty 55-gal. drums & $\begin{array}{l}\text { Materials had previously been } \\
\text { removed. No further action } \\
\text { required. }\end{array}$ \\
\hline $11-22-09$ & $\begin{array}{l}\text { lem and additional materials } \\
\text { were removed. No further action } \\
\text { required. }\end{array}$ \\
\hline $11-24-01$ & (1) drum & $\begin{array}{l}\text { The batteries had previously } \\
\text { been removed. Remaining } \\
\text { debris was retrieved and } \\
\text { disposed. No further action } \\
\text { required. }\end{array}$ \\
\hline
\end{tabular}




\section{FFACO CORRECTIVE ACTION SITE HOUSEKEEPING CLOSURE VERIFICATION FORM}

Closure Verification Date: 08 -SEP-97

CAS Number: 05-22-01

General Location: Sugar Bunker

Latitude: $36^{\circ} 50^{\prime} 23^{\prime \prime}$

Longitude: $115^{\circ} 57^{\prime} 38^{\prime \prime}$

\author{
CAU Number: 347 \\ Elevation: \\ Northing: \\ Easting:
}

Coordinate/Elevation Data Obtained from Garmen 40 Global Position System: Accuracy is within $300 \mathrm{ft}$ Horizontal - Vertical Varies with Locality

Site Access Route: Mercury Hwy north to 5-01 Rd. Go straight (north) on 5-01 Rd and proceed past 5-07 Rd for approx. $1.0 \mathrm{mi}$. Turn left (west) on gravel road, proceeding $0.3 \mathrm{mi}$ to Sugar Bunker, a former chemical explosives storage unit. The CAS markers are at the NW corner and on the south side of the bunker.

\begin{tabular}{|c|l|}
\hline Waste Item(s) Originally at Site & \multicolumn{1}{c|}{ Apparent Waste Type* } \\
\hline Drums (4), Gas Cans (3), Vehicle Gas Tank \& Battery & Radioactive, Ordinary \& Recyclable \\
\hline
\end{tabular}

* Ordinary, Scrap Metal, Asbestos, PCB, Salvageahle, Hazardous, Radioactive, Mixed, Unknown, Other

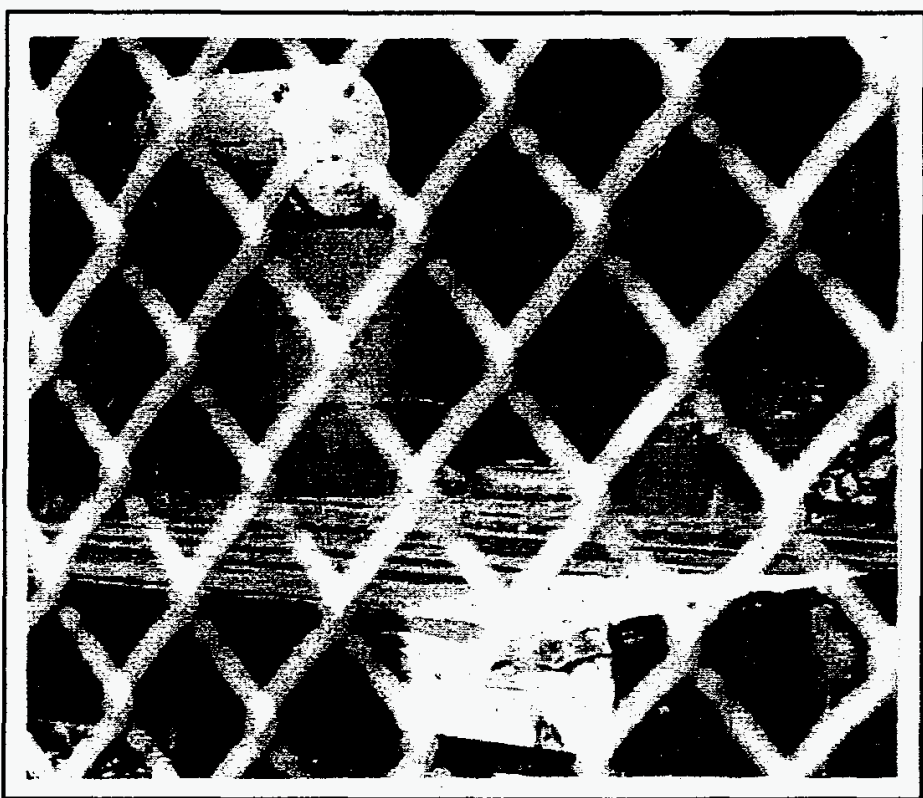

CAS Prior to Cleanup

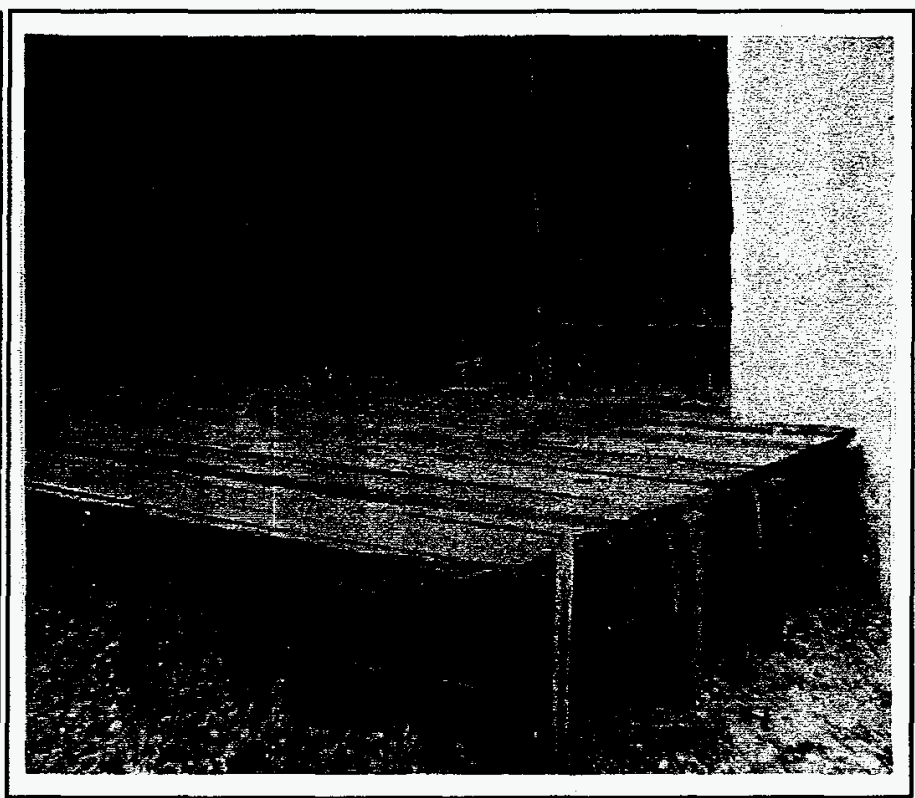

CAS After Cleanup

\section{Current Site Description/Observations:}

Originally identified on 13-SEP-90 and 21-SEP-90, two drums containing beryllium/uranium contaminated waste, three gas cans, and a battery had previously been removed from this location. NTS personnel retrieved one empty 55-gallon drum and an empty gas tank for disposal at the Area 23 Landfill. The Sugar Bunker is abandoned and is no longer being used for magazine storage.

No Further Action Required at Corrective Action Site

C. Carlos Gonzales

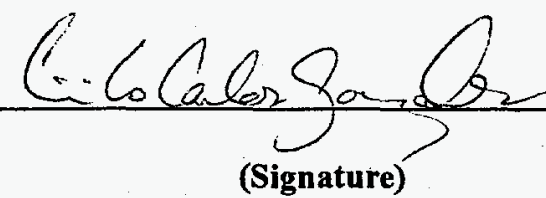
$1-6-98$ 


\section{FFACO CORRECTIVE ACTION Site HOUSEKEEPING CLOSURE VERIFICATION FORM}

Closure Verification Date: 19-SEP-97

CAS Number: 05-22-13

General Location: Old Mercury Hwy

Latitude:

Longitude:
CAU Number: 347

Elevation:

Northing:

Easting:

Coordinate/Elevation Data Obtained from Garmen 40 Global Position System: Accuracy is within $300 \mathrm{ft}$ Horizontal -.Vertical Varies with Locality

Site Access Route: North of Mercury on Mercury Hwy, veering right (east) prior to arriving at junction of Mercury Hwy and Old Mercury Hwy (the turn-off is $0.3 \mathrm{mi} \mathrm{S}$ of junction). Head east for approximately $0.7 \mathrm{mi}$. Remains of an old, weathered security barricade lies at the top of the hill where the CAS was identified. No markers could be found which would identify the exact location.

\begin{tabular}{|l|l|}
\hline \multicolumn{1}{|c|}{ Waste Item(s) Originally at Site } & \multicolumn{1}{c|}{ Apparent Waste Type* $^{*}$} \\
\hline Drums; Battery & Unknown; Recyclable \\
\hline
\end{tabular}

* Ordinary, Scrap Metal, Asbestos, PCB, Salvageable, Hazardous, Radioactive, Mired, Unknown, Other

No Photo Available of CAS Prior To Cleanup

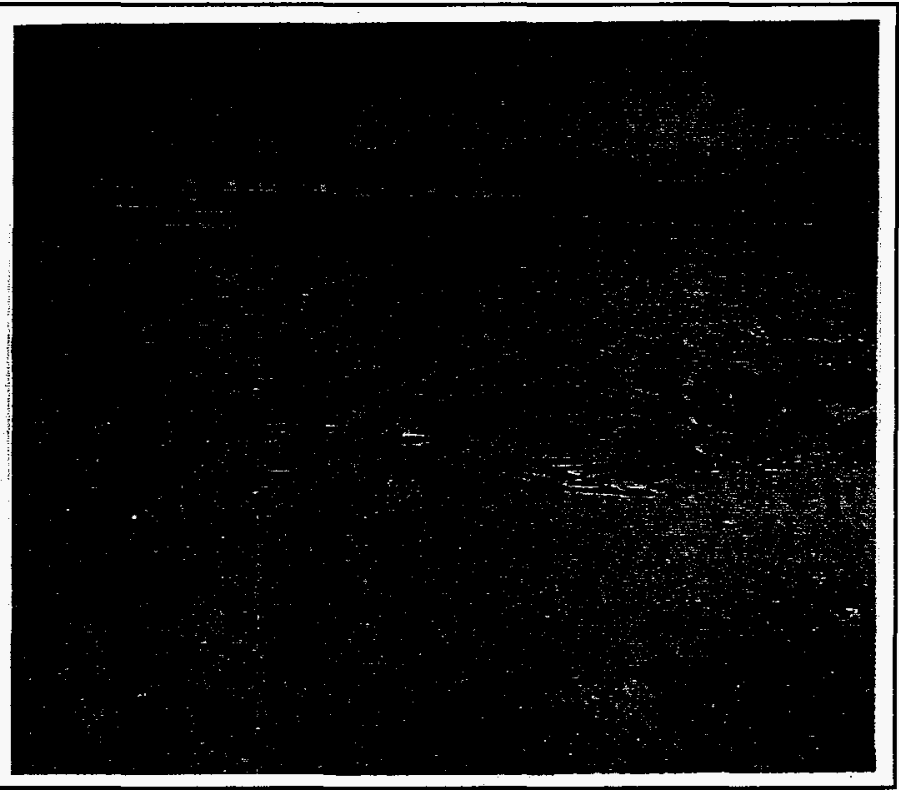

CAS After Cleanup

Current Site Description/Observations: Originally identified on 26-SEP-90, this CAS consisted of two barrels of unknown content, located along the NW side of a security barricade on a hill. A battery had also been identified and it is believed that the battery was issued CAS number 05-24-03. NTS personnel visited both CASs; no marker or drums were found near the old barricade, and only the bottom portion of a marker was found at the former battery site (previously retrieved). Miscellaneous trash and debris were found near the Mercury Hwy/Old Mercury Hwy junction, which was retrieved for disposal at the Area 23 Landfill.

No Further Action Required at Corrective Action Site

C. Carlos Gonzales
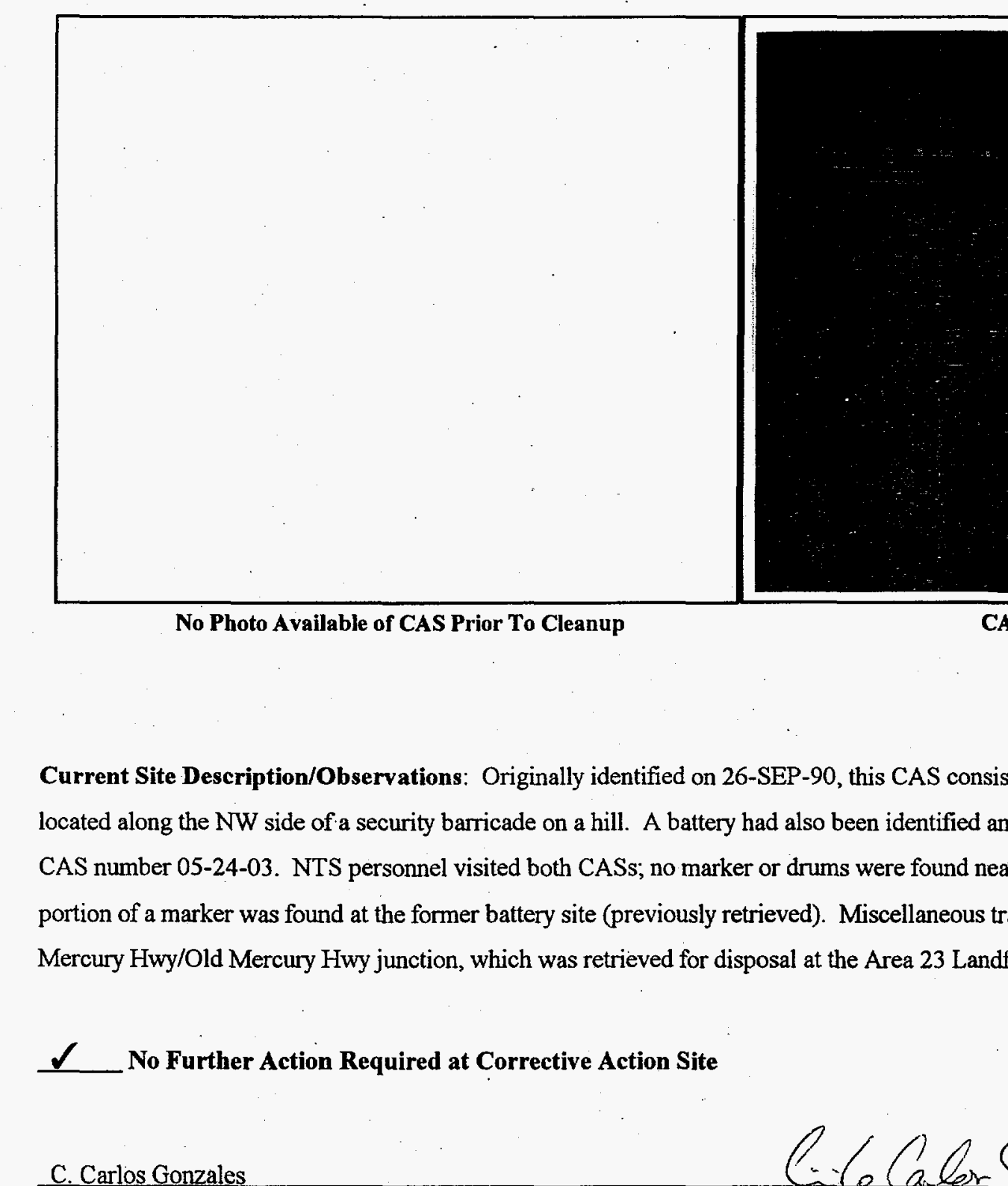

$2\left[\begin{array}{llcl}\text { C. Carlos Gonzales } \\ \text { Corrective Action Coordinator/Designee }\end{array}\right.$

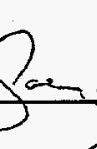




\section{FFACO CORRECTIVE ACTION SITE HOUSEKEEPING CLOSURE VERIFICATION FORM}

Closure Verification Date: 13-SEP-97

CAS Number: 05-22-06

General Location: Gate 200/RSM M-9

CAU Number: 347

Latitude: $36^{\circ} 41^{\prime} 38^{\prime \prime}$

Elevation:

Longitude: $115^{\circ} 58^{\prime} 26^{\prime \prime}$

Northing:

Easting:

Coordinate/Elevation Data Obtained from Garmen 40 Global Position System: Accuracy is within $300 \mathrm{ft}$ Horizontal - Vertical Varies with Locality

Site Access Route: North of Mercury on Mercury Hwy towards Gate 200. Location of actual CAS could not be determined due to naccurate driving instructions recorded on the original inventory form. CAS stakes were placed at Rad-Safe Markers (RSM) M-3 and M-9 and GPS coordinates were recorded at RSM M-9 on 17-APR-96.

\begin{tabular}{|l|l|}
\hline \multicolumn{1}{|c|}{ Waste Item(s) Originally at Site } & \\
\hline (1) 55-gallon Drum with Contents & Unknown \\
\hline
\end{tabular}

- Ordinary, Scrap Metal, Asbestos, PCB, Salvageable, Hazardous, Radioactive, Mixed, Unknown, Other

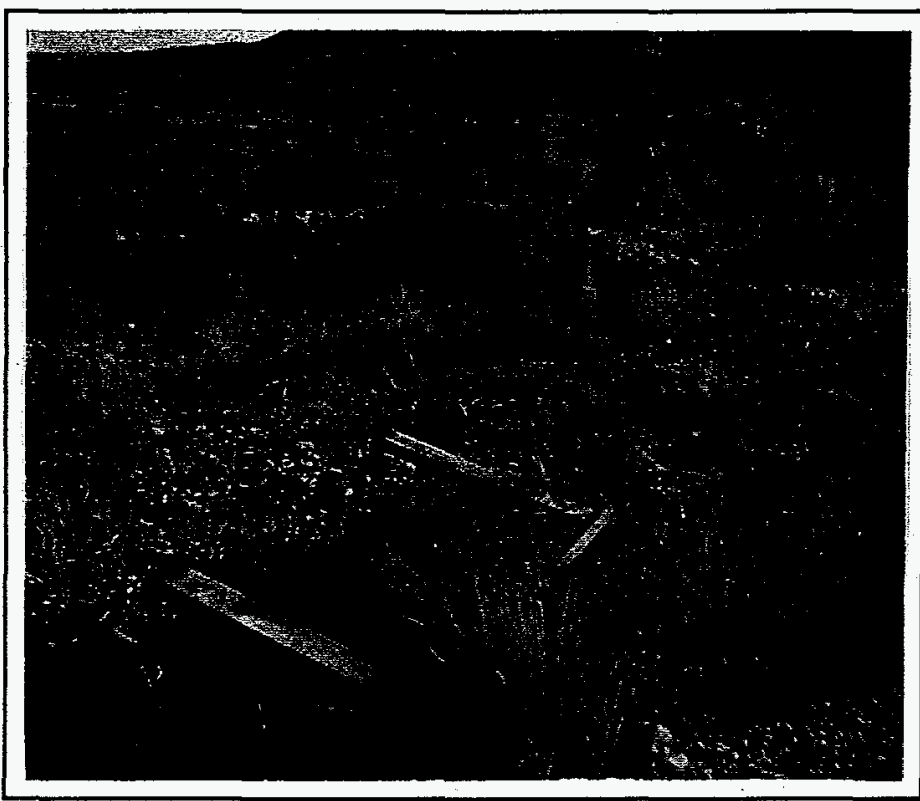

CAS Prior To Cleanup

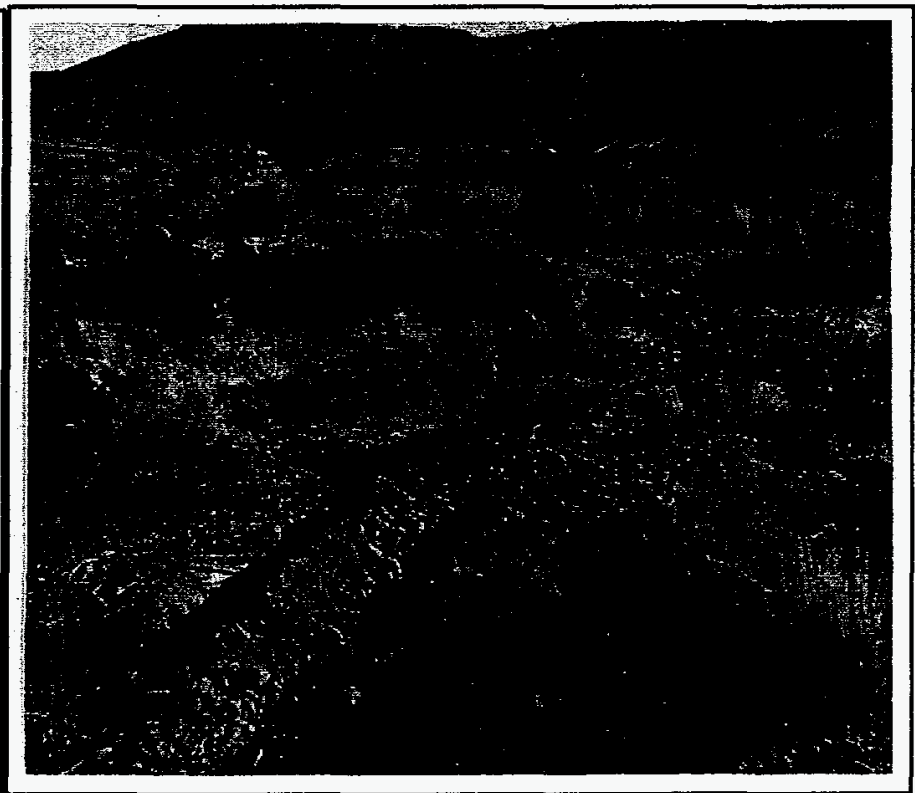

CAS After Cleanup

Current Site Description/Observations: Originally identified 08-OCT-90, this CAS consisted of one 55-gallon drum containing unknown contents. No drum was ever found by field crews along the described area (south of Gate 200 and south of Booster Station \#4) Solid waste debris and recyclable lead materials were retrieved from the west side of Mercury Hwy area near RSM M-9. The waste was disposed at the Area 23 Landfill, and the lead was recycled through Property and Supply.

No Further Action Required at Corrective Action Site

C. Carlos Gonzales

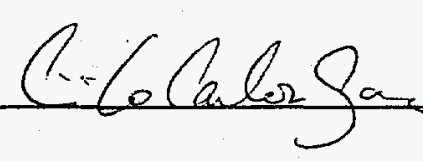




\section{FFACO CORRECTIVE ACTION Site HOUSEKEEPING CLOSURE VERIFICATION FORM}

Closure Verification Date: 28 -SEP-97

$\begin{array}{rlr}\text { CAS Number: } & 05-22-15 & \text { CAU Number: } 347 \\ \text { General Location: } & \text { GMX Facility } & \text { Elevation: } \\ : \text { Latitude: } & 36^{\circ} 50^{\prime} 36^{\prime} & \text { Northing: } \\ \text { Longitude: } & 115^{\circ} 56^{\prime} 24^{\prime \prime} & \text { Easting: }\end{array}$

Coordinate/Elevation Data Obtained from Garmen 40 Global Position System: Accuracy is within $300 \mathrm{ft} \mathrm{Horizontal} \mathrm{-} \mathrm{Vertical} \mathrm{Varies} \mathrm{with} \mathrm{Locality}$

Site Access Route: North of Mercury on Mercury Hwy, veering north on the 5-01 Rd. Proceed for 7.7 mi to dirt road on right (east) side (60 feet north of RSM 5Y 14). Take dirt road for $0.4 \mathrm{mi}$, turn left (north) at intersection, proceeding $0.5 \mathrm{mi}$. At next dirt road, turn right (east) owards the GMX fenced area and drive around to the east side of the compound.

\begin{tabular}{|l|l|}
\hline \multicolumn{1}{|c|}{ Waste Item(s) Originally at Site } & \multicolumn{1}{c|}{ Apparent Waste Type* $^{*}$} \\
\hline (1) Drum & Unknown \\
\hline
\end{tabular}

* Ordinary, Scrap Metal, Asbestos, PCB, Salvageable, Hazardous, Radioactive, Mixed, Unknown, Other

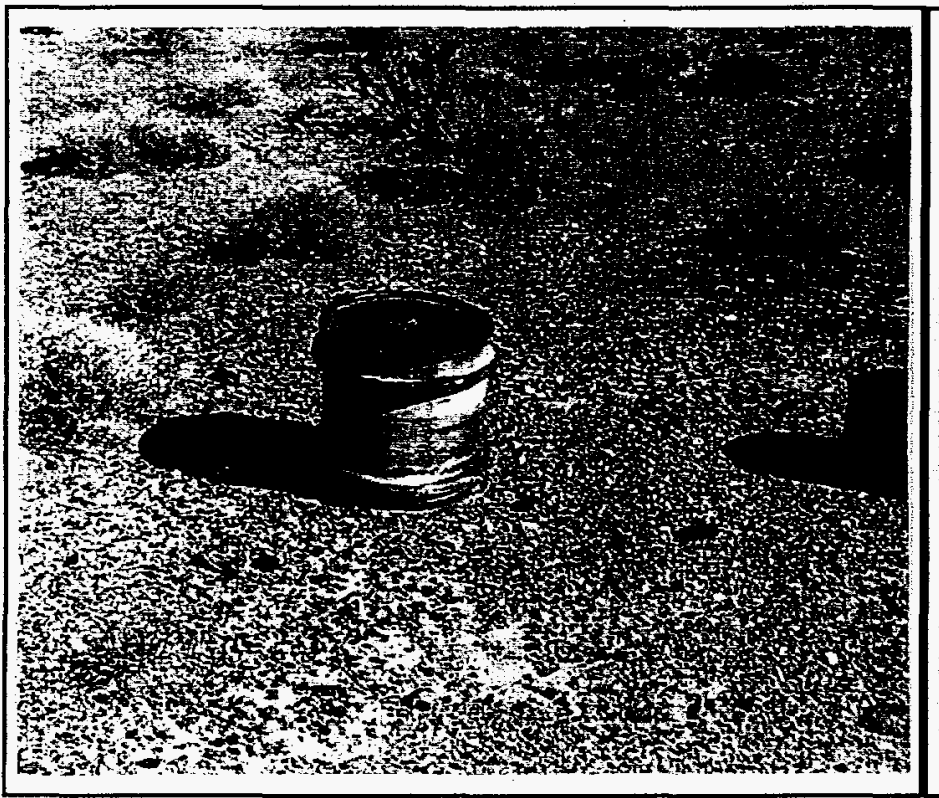

CAS Prior To Cleanup

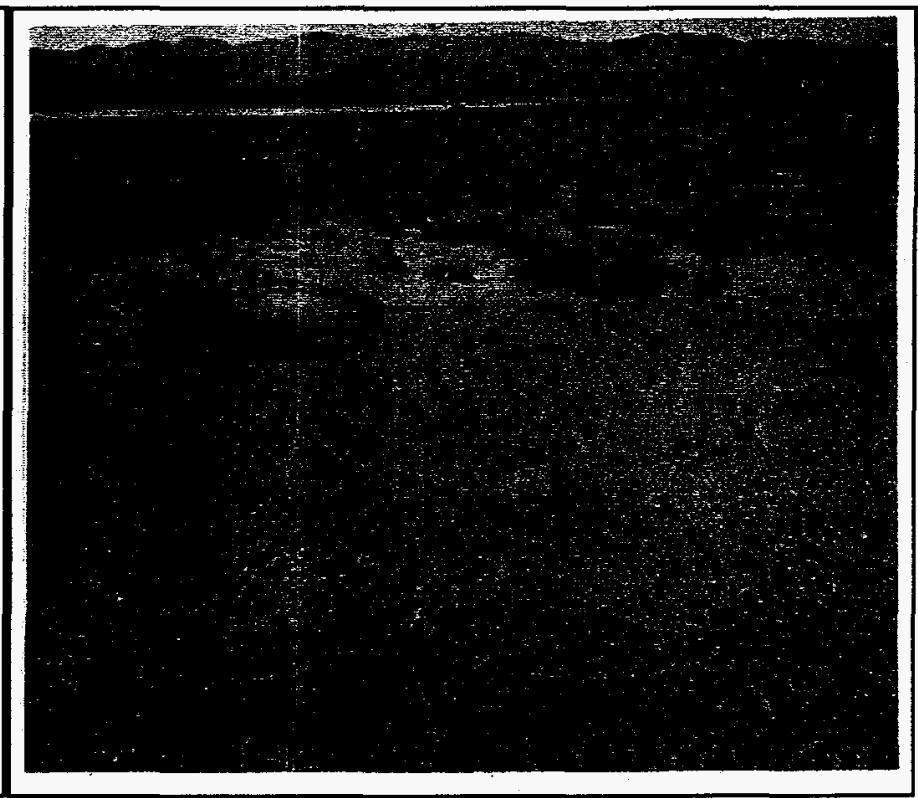

CAS After Cleanup

Current Site Description/Observations: Originally identified on 29-JAN-91, the drum was suspected to be an ammunition container, although the photograph resembles that of a smoke pot. NTS field crews located a site identified as 05-22-15 at the GMX fenceline on 17APR-96 and conducted a GPS survey. A marker for the actual CAS could not be found, but an old photo was found in the field files indicating that the package had previously been retrieved. Also found was a May 1992 memo to DOE/NV with a list of CASs that had been cleaned; the list included 05-22-15.

No Further Action Required at Corrective Action Site

C. Carlos Gonzales

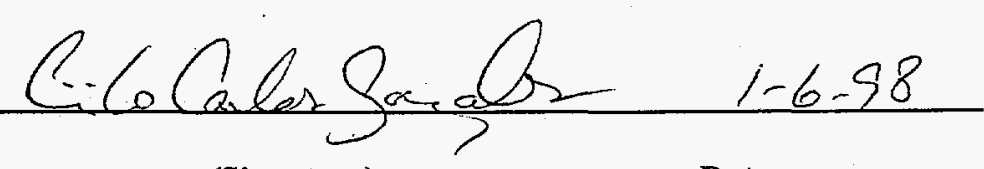

Corrective Action Coordinator/Designee

(Signature)

Date 


\section{FFACO CORRECTIVE ACTION SITE HOUSEKEEPING ClOSURE VERIFICATION FORM}

Closure Verification Date: $27-$ SEP-97

CAS Number: 05-22-17

General Location: Gravel Gertie

CAU Number: 347

Latitude:

Elevation:

Longitude:

Northing: $733,926.074$

Easting: $705,348.668$

Coordinate/Elevation Data Obtained from Garmen 40 Global Position System: Accuracy is within $300 \mathrm{ft} \mathrm{Horizontal} \mathrm{-} \mathrm{Vertical} \mathrm{Varies} \mathrm{with} \mathrm{Locality}$

Site Access Route: North of Mercury on Mercury Hwy, veering north on the 5-01 Rd. Proceed to the aggregate pit located along the right (east) side of the 5-01 Rd (east of the Gravel Gertie HE Test Bunker). Turn right (east) on dirt road and proceed 0.15 mi towards mounds of gravel on north side of road; the CAS lies in a pit approximately 150 feet NE of the gravel mounds and is identified with a wood marker.

\begin{tabular}{|l|l|}
\hline \multicolumn{1}{|c|}{ Waste Item(s) Originally at Site } & \multicolumn{1}{c|}{ Apparent Waste Type* $^{*}$} \\
\hline (1) Drum & Ordinary \\
\hline
\end{tabular}

* Ordinary, Scrap Metal, Ashestos, PCB, Salvageable, Hazardous, Radioactive, Mixed, Unknown, Other

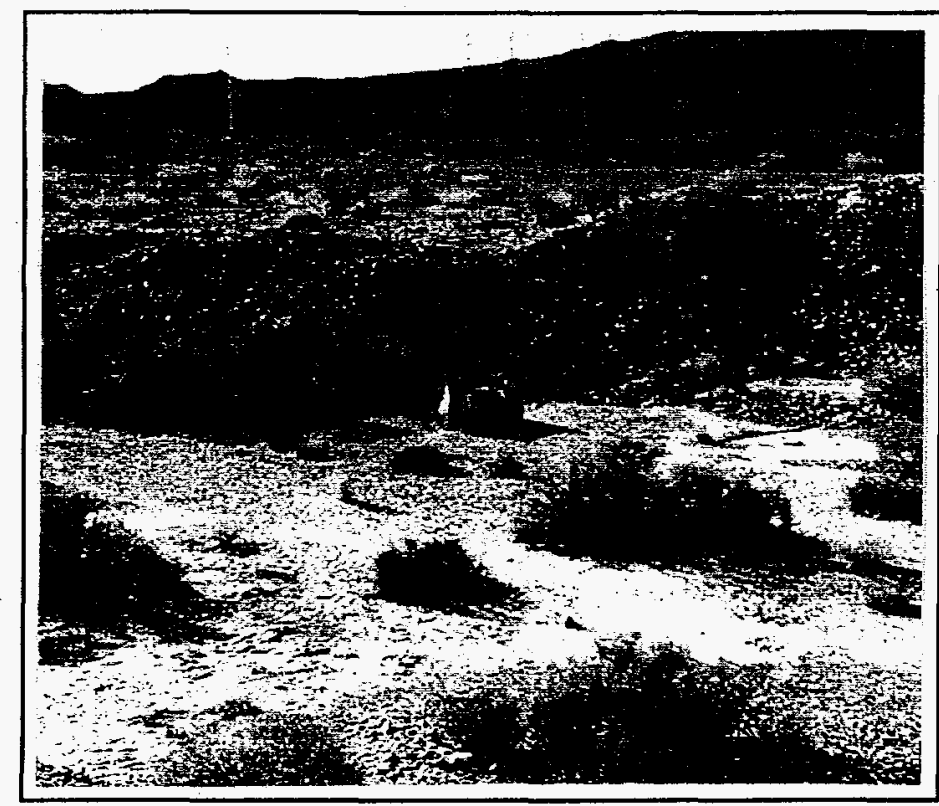

CAS Prior To Cleanup

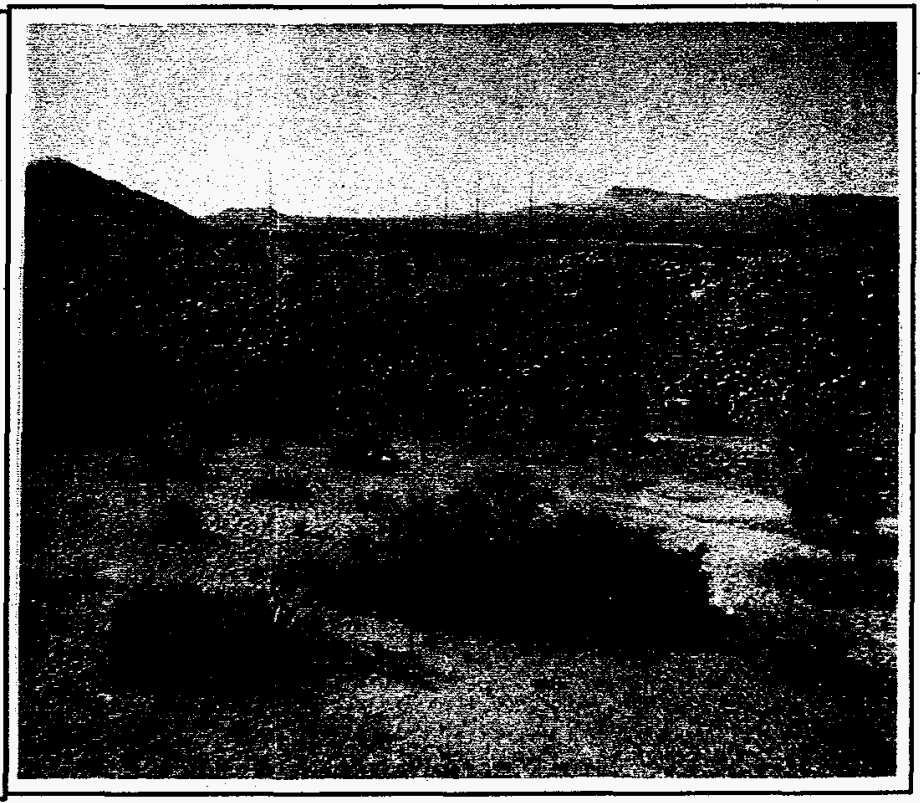

CAS After Cleanup

Current Site Description/Observations: Originally identified on 14-DEC-90, the empty metal drum was retrieved for disposal, along with an empty 30-gal. drum (found partially buried nearby) and miscellaneous metal debris. Other debris, such as cable, metal, and glass, found in the surrounding area, were also retrieved for disposal. All debris was disposed of at the Area 23 Landfill.

No Further Action Required at Corrective Action Site

C. Carlos Gonzales

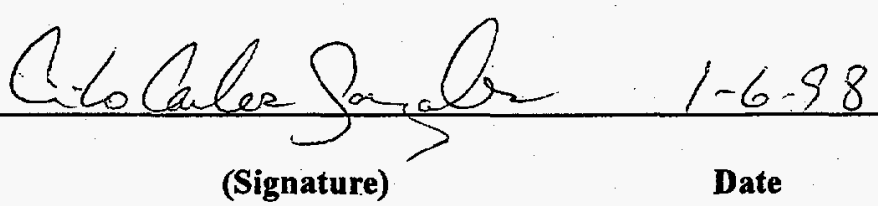




\section{FFACO CORRECTIVE ACTION SITE HOUSEKEEPING ClOSURE VERIFICATION FORM}

Closure Verification Date: $30-$ SEP-97

$\begin{array}{rlr}\text { CAS Number: } & 05-22-20 & \text { CAU Number: } \\ \text { General Location: } & \text { Frenchman Lake } & \text { Elevation: } \\ \text { Latitude: } & \text { Northing: } \\ \text { Longitude: } & \text { Easting: }\end{array}$

Coordinate/Elevation Data Obtained from Garmen 40 Global Position System: Accuracy is within $300 \mathrm{ft} \mathrm{Horizontal} \mathrm{-} \mathrm{Vertical} \mathrm{Varies} \mathrm{with} \mathrm{Locality}$

Site Access Route: North of Mercury on Mercury Hwy, veering north on the 5-01 Rd. Proceed $4.0 \mathrm{mi}$ to the 5-05 Rd and turn right (east) owards the Spill Test Facility. Proceed approx. $0.9 \mathrm{mi}$ to the south end of the motel-like structure and turn left (north), traveling towards the NW edge of the lakebed. (Originally, an "airstrip" had been associated with this location, but no airstrip ever existed on Frenchman Lake.)

\begin{tabular}{|l|l|}
\hline \multicolumn{1}{|c|}{ Waste Item(s) Originally at Site } & \multicolumn{1}{c|}{ Apparent Waste Type* $^{\text {Apty }}$} \\
\hline (1) Drum (empty) & Ordinary \\
\hline
\end{tabular}

- Ordinary, Scrap Metal, Asbestos, PCB, Salvageable, Hazardous, Radioactive, Mixed, Unknown, Other

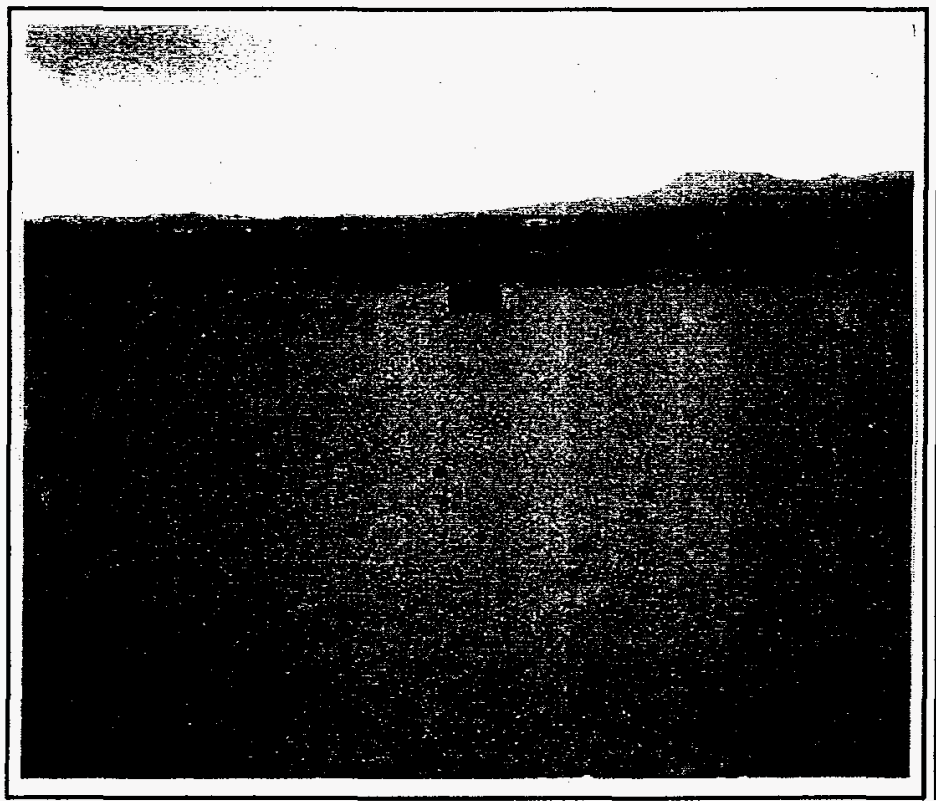

CAS Prior To Cleanup

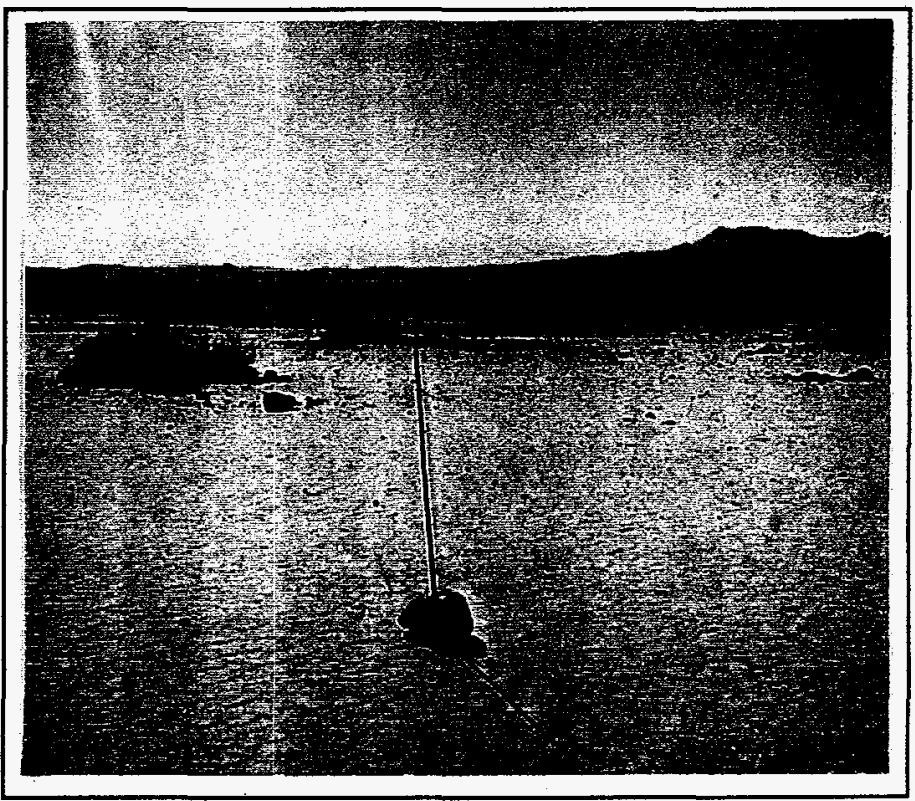

CAS After Cleanup

Current Site Description/Observations: Originally identified on 24-JAN-91 as an empty drum, the field file contains an old photo showing a clean site and a May 1992 memo to DOE/NV with a list of CASs that were cleaned, including 05-22-20. The field file also contains sampling and analysis data for a liquid sample identified as being collected from 05-22-20. Field crews placed a CAS marker at the location on 26-SEP-96 and it was verified on 30-SEP-97 that no drum or debris remain at this site.

No Further Action Required at Corrective Action Site

C. Carlos Gonzales

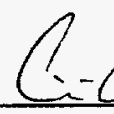




\section{FFACO CORRECTIVE ACTION SITE HOUSEKEEPING CLOSURE VERIFICATION FORM}

Closure Verification Date: 26-SEP-97

CAS Number: $05-22-22$

General Location: Gravel Gertie

CAU Number: 347

Latitude:

Elevation:

Longitude:

Northing: $733,500.234$

Easting: $\quad 704,907.070$

Coordinate/Elevation Data Obtained from Garmen 40 Global Position System: Accuracy is within $300 \mathrm{ft}$ Horizontal - Vertical Varies with Locality

Site Access Route: North of Mercury on Mercury Hwy, veering north on the 5-01 Rd. Proceed to the aggregate pit located along the right (east) side of the 5-01 Rd (east of the Gravel Gertie HE Test Bunker). Turn right (east) on dirt road into the gravel pit area, going east 150 ards. The CAS is located inside a deep pit, 175 feet south of the dirt road.

\begin{tabular}{|l|l|}
\hline \multicolumn{1}{|c|}{ Waste Item(s) Originally at Site } & \multicolumn{1}{c|}{ Apparent Waste Type* $^{*}$} \\
\hline (1) Drum (empty) & Ordinary \\
\hline
\end{tabular}

* Ordinary, Scrap Metal, Asbestos, PCB, Salvageable, Hazardous, Radioactive, Mixed, Unknown, Other

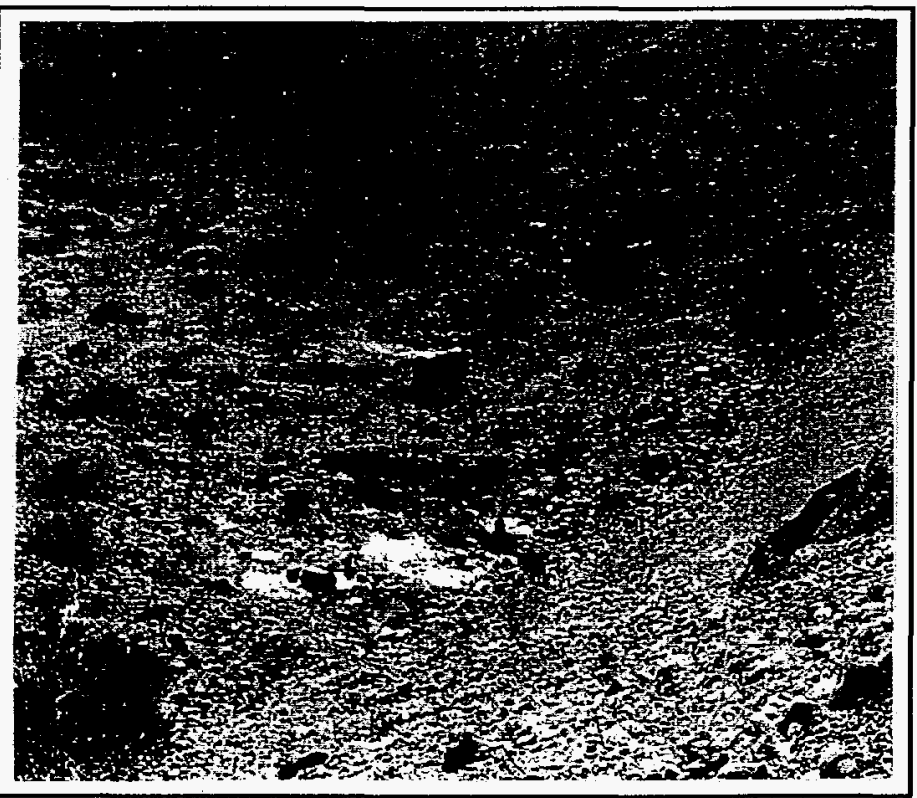

CAS Prior To Cleanup

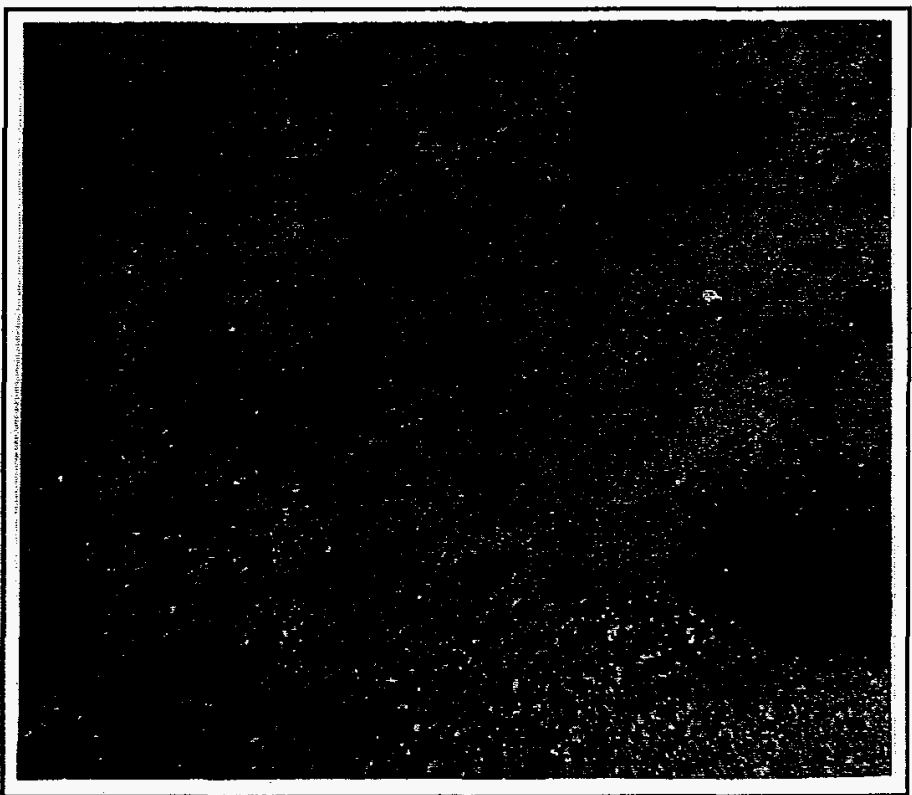

CAS After Cleanup

Current Site Description/Observations: Originally identified on 14-DEC-90, the empty drum, miscellaneous empty metal containers, cable and other debris were retrieved for disposal at the Area 9 U10c and Area 23 landfills by NTS personnel.

No Further Action Required at Corrective Action Site

C. Carlos Gonzales

Corrective Action Coordinator/Designee

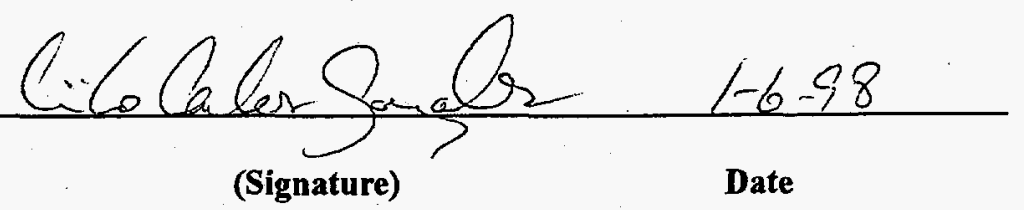

(Signature)

Date 


\section{FFACO CORRECTIVE ACTION SITE HOUSEKEEPING ClOSURE VERIFICATION FORM}

Closure Verification Date: $\quad 08-S E P-97$

$\begin{array}{rlrl}\text { CAS Number: } & 05-22-23 & \text { CAU Number: } & 347 \\ \text { General Location: } & \text { Frenchman Lake } & \text { Elevation: } & \\ \text { Latitude: } & \text { Northing: } & 750,901.257 \\ \text { Longitude: } & \text { Easting: } & 710,469.734\end{array}$

Coordinate/Elevation Data Obtained from Garmen 40 Global Position System: Accuracy is within $300 \mathrm{ft}$ Horizontal - Vertical Varies with Locality

Site Access Route: North of Mercury on Mercury Hwy, veering north on the 5-01 Rd. Proceed to the 5-03 Rd, turn right (east) towards he Spill Test Facility tanks. The CAS is located on the lakebed due north of the tanks, along the Cambric Ditch bank, behind a large mound of dirt. A CAS marker is located at the former waste site.

\begin{tabular}{|l|l|}
\hline \multicolumn{1}{|c|}{ Waste Item(s) Originally at Site } & \multicolumn{1}{c|}{ Apparent Waste Type* $^{*}$} \\
\hline (1) 30-gal. Drum (empty) & Ordinary \\
\hline
\end{tabular}

* Ordinary, Scrap Metal, Asbestos, PCB, Salvageable, Hazardous, Radioactive, Mixed, Unknown, Other

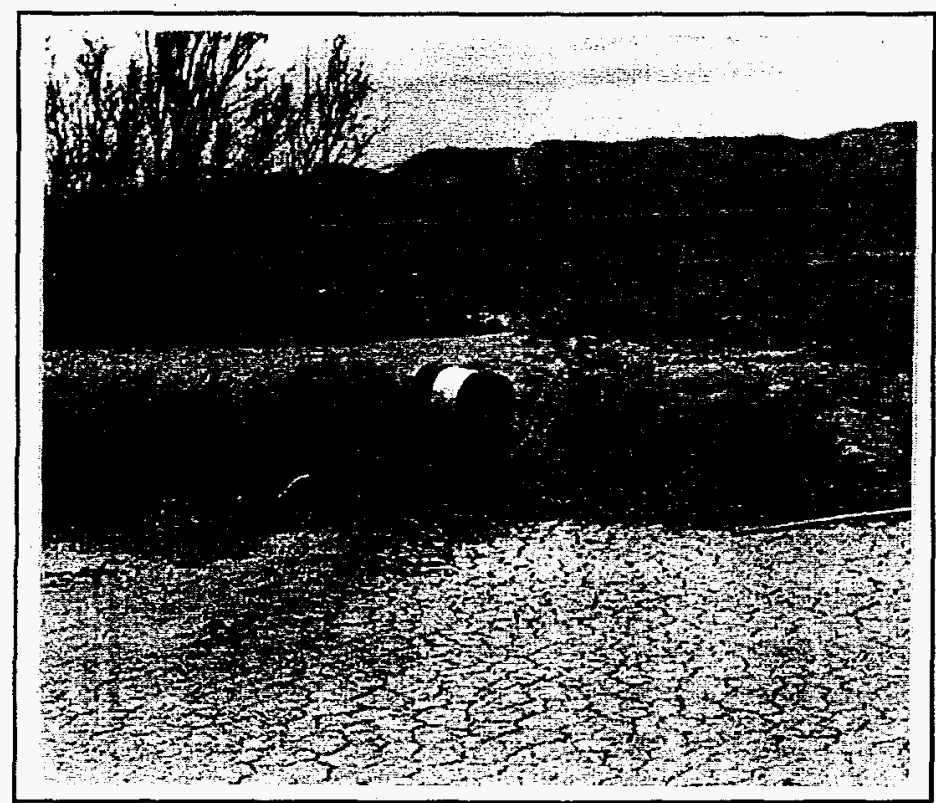

CAS Prior To Cleanup

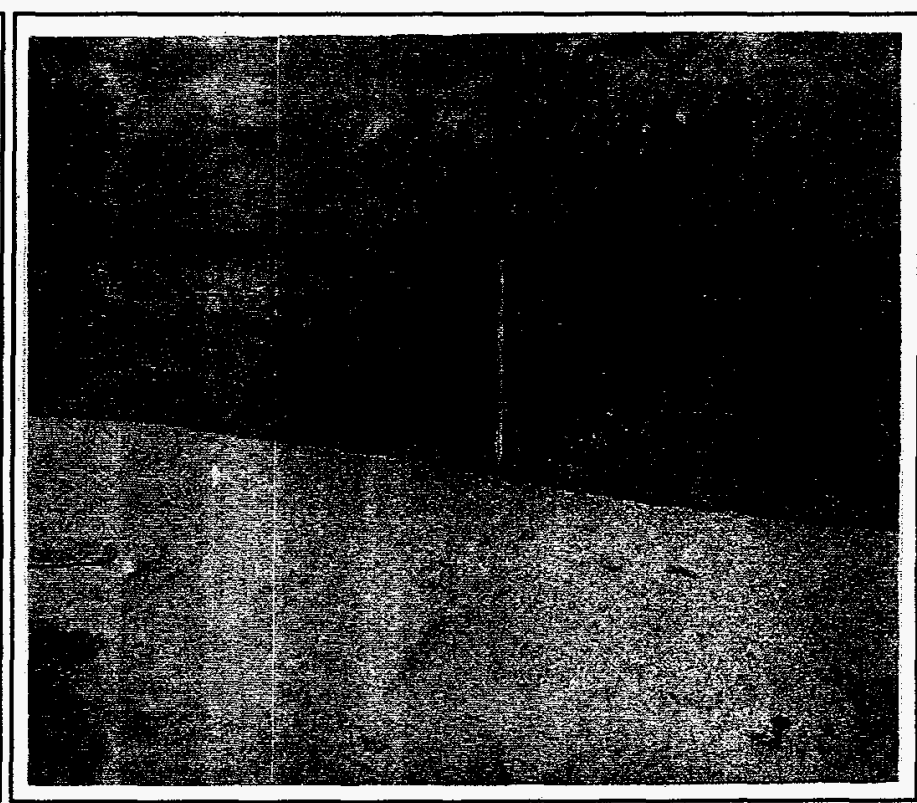

CAS After Cleanup

Current Site Description/Observations: Originally identified on 14-DEC-90, the empty metal drum and several plastic buckets were recovered for disposal at the Area 23 Landfill by NTS personnel. Field crews had previously reported on 27-APR-94 that the drum had been removed, and an undated photo in the field files show that the site had been cleaned. The metal drum was found in brush along the north side of the ditch bank with the other containers.

No Further Action Required at Corrective Action Site

C. Carlos Gonzales

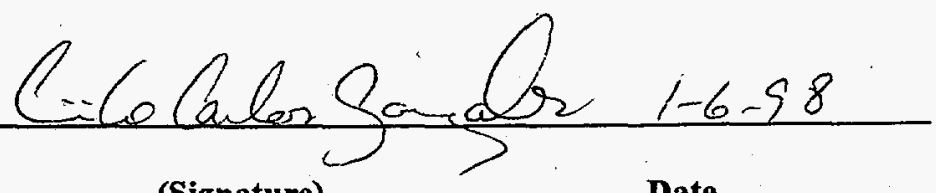




\section{FFACO CORRECTIVE ACTION SITE HOUSEKEEPING CLOSURE VERIFICATION FORM}

Closure Verification Date: $\quad$ 26-SEP-97

CAS Number: 05-22-24

General Location: Gravel Gertie

Latitude:

Longitude:

\author{
CAU Number: 347 \\ Elevation: \\ Northing: $733,464.470$ \\ Easting: $705,195.783$
}

Coordinate/Elevation Data Obtained from Garmen 40 Global Position System: Accuracy is within $300 \mathrm{ft}$ Horizontal - Vertical Varies with Locality

Site Access Route: North of Mercury on Mercury Hwy, veering north on the 5-01 Rd. Proceed to the aggregate pit located along the right (east) side of the 5-01 Rd (east of the Gravel Gertie HE Test Bunker). Turn right (east) on dirt road into the gravel pit area, going east 200 yards. The CAS is located 190 feet south of the dirt road in a pit previously containing a debris pile.

\begin{tabular}{|l|l|}
\hline \multicolumn{1}{|c|}{ Waste Item(s) Originally at Site } & \multicolumn{1}{|c|}{ Apparent Waste Type* $^{*}$} \\
\hline (1) Crushed Drum (empty) & Ordinary \\
\hline
\end{tabular}

- Ordinary, Scrap Metal, Ashestos, PCB, Salvageable, Hazardous, Radioactive, Mixed, Unknown, Other

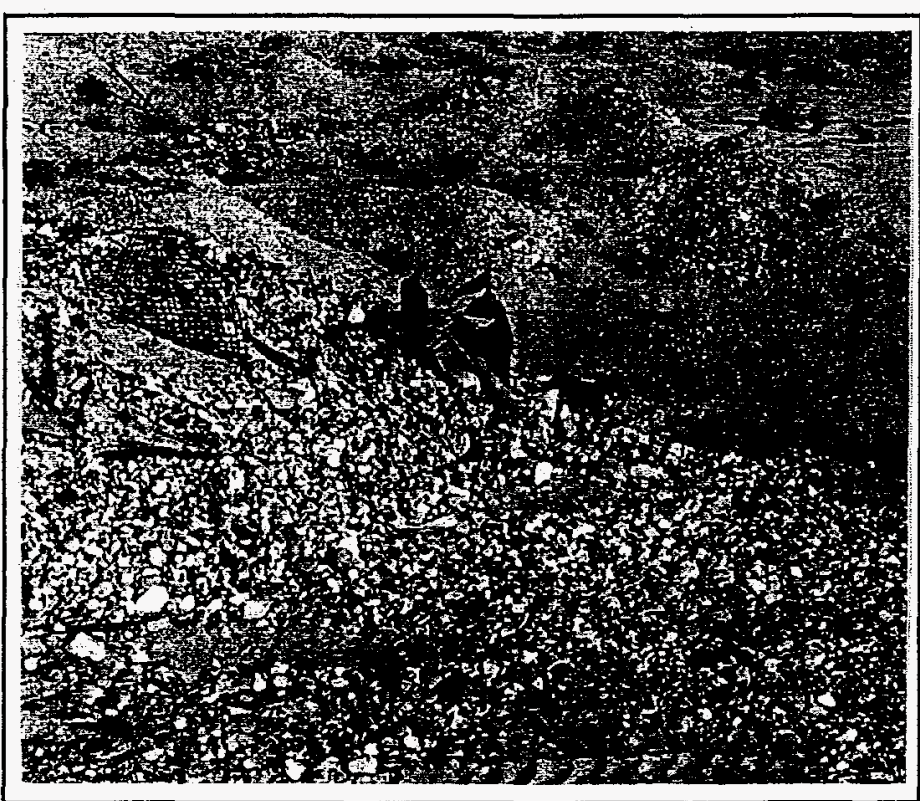

CAS Prior To Cleanup

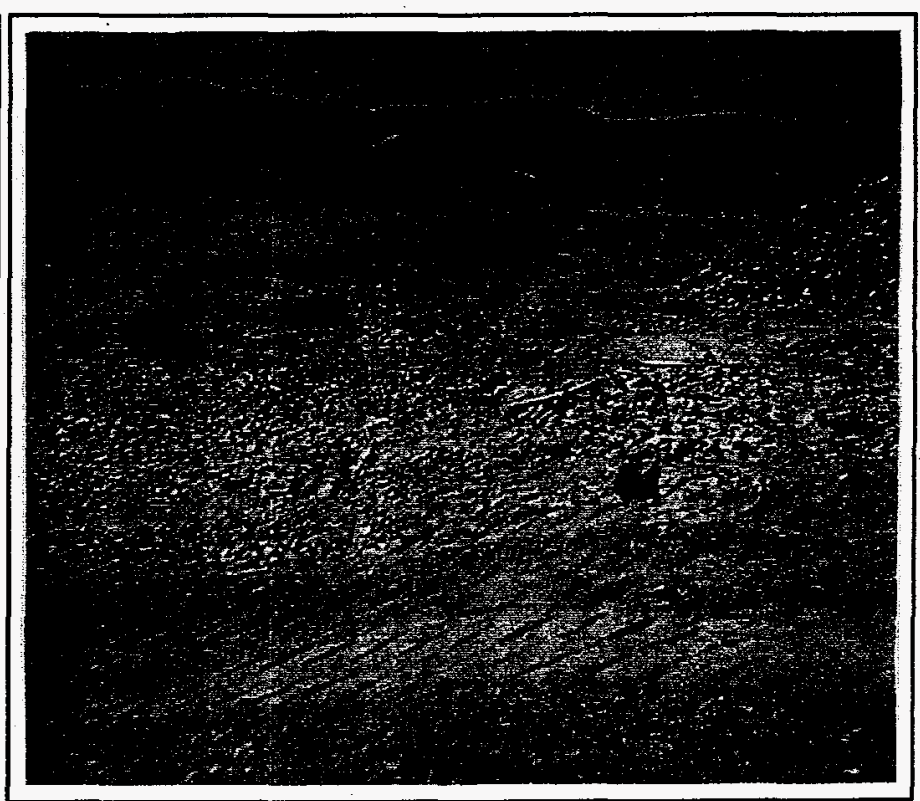

CAS After Cleanup

Current Site Description/Observations: Originally identified on 24-JAN-91, the empty metal drum and a large debris pile were retrieved for disposal at the Area 9 U10c and Area 23 landfills. Also picked up were debris and empty containers located in nearby gravel pits (to the south and northwest). An undated photo, identified as "05-22-24", was found in the field file showing that the drum and debris pile had been cleaned, but NTS field crews verified on 04-AUG-93 that the drum and debris were still present at this location.

No Further Action Required at Corrective Action Site

C. Carlos Gonzales

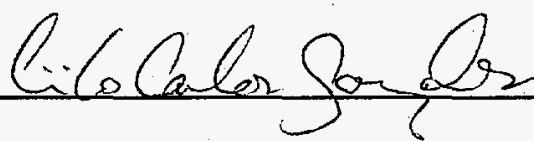




\title{
FFACO CORRECTIVE ACTION SITE HOUSEKEEPING ClOSURE VERIFICATION FORM
}

Closure Verification Date: $18-A P R-97$

CAS Number: 05-22-39

General Location: USe Well

\author{
CAU Number: 347 \\ Elevation: \\ Northing: $755,016.881$ \\ Easting: $704,758.733$
}

Latitude:

Longitude:

Coordinate/Elevation Data Obtained from Garmen 40 Global Position System: Accuracy is within $300 \mathrm{ft} \mathrm{Horizontal} \mathrm{-} \mathrm{Vertical} \mathrm{Varies} \mathrm{with} \mathrm{Locality}$

Site Access Route: North of Mercury on Mercury Hwy, veering north on the 5-01 Rd. Proceed past the 5-03 Rd to Cambric Ditch, urning left (west) $0.5 \mathrm{mi}$ to the wellhead (travel along the south side of the ditch). From the wellhead, the CAS is located S-SW approx. 200 owards the northern edge of a pit. A CAS marker is located on the north bank of the pit.

\begin{tabular}{|l|l|}
\hline \multicolumn{1}{|c|}{ Waste Item(s) Originally at Site } & \multicolumn{1}{c|}{ Apparent Waste Type $^{*}$} \\
\hline (1) 5-gal Bucket & Ordinary \\
\hline
\end{tabular}

* Ordinary, Scrap Metal, Ashestos, PCB, Salvageable, Hazardous, Radioactive, Mixed, Unknown, Other

No Photo Available of CAS Prior To Cleanup

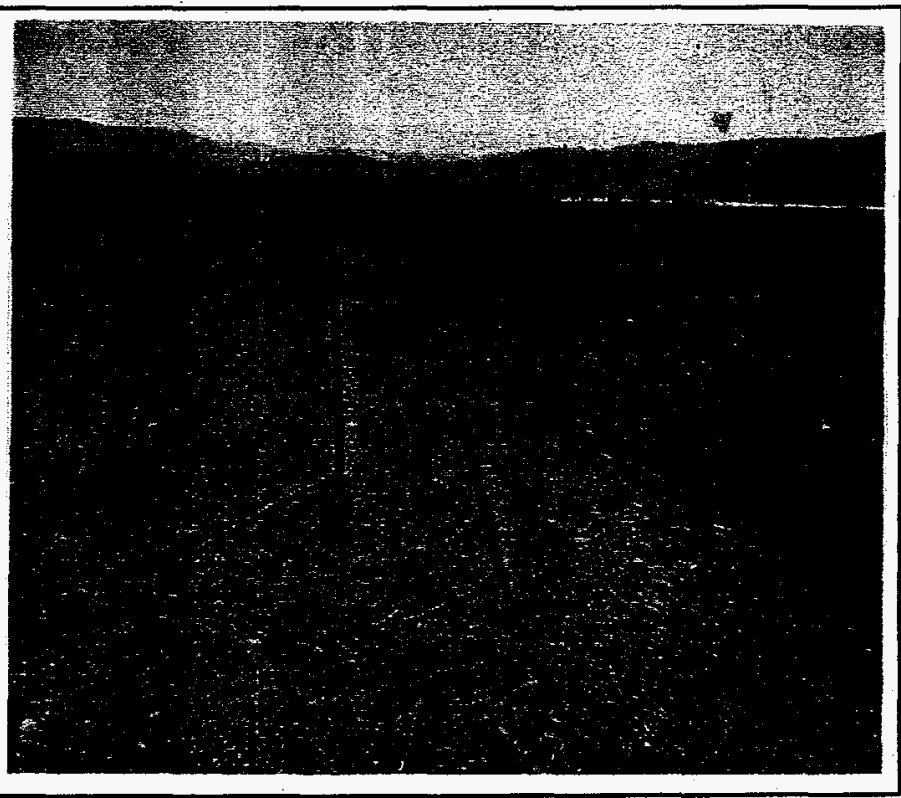

CAS After Cleanup

Current Site Description/Observations: Originally identified by field crews on 26-AUG-93, a bucket was found caked with what appeared to be mud. The bucket was no longer there when NTS personnel returned to the area for cleanup operations. Although no record exists, the bucket may have been retrieved during previous cleanup of the area surrounding the Cambric wellhead. A CAS marker remains at the former cleanup site.

No Further Action Required at Corrective Action Site

C. Carlos Gonzales
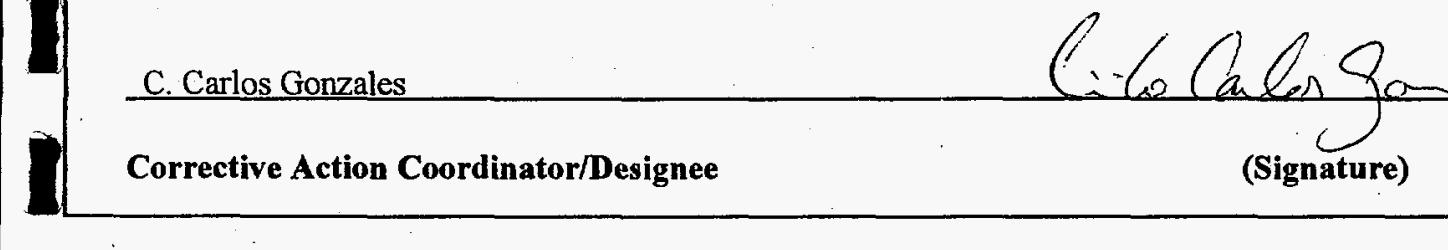

(Signature) $1-6-98$ Date 


\title{
FFACO CORRECTIVE ACTION SITE HoUSEKEEPING ClOSURE VERIFICATION FORM
}

Closure Verification Date: 12 -SEP-97

\author{
CAS Number: $05-24-06$ \\ General Location: Frenchman Lake @ H Rd \\ Latitude: \\ Longitude:
}

\author{
CAU Number: 347 \\ Elevation: \\ Northing: $754,229.089$ \\ Easting: $713,073.651$
}

Coordinate/Elevation Data Obtained from Garmen 40 Global Position System: Accuracy is within $300 \mathrm{ft}$ Horizontal - Vertical Varies with Locality

Site Access Route: North of Mercury on Mercury Hwy, veering north on the 5-01 Rd up to the road leading to Sugar Bunker. Turn right (east - opposite Sugar Bunker) on dirt road (P-Rd) for $0.8 \mathrm{mi}$. At end of road, turn right (south - H Rd) along barbed wire fence for $1.2 \mathrm{mi}$ fowards Frenchman Lake. The CAS is approximately 3-4 acres, with a marker placed 50 feet left (east) of the road near edge of lake bed.

\begin{tabular}{|l|l|}
\hline \multicolumn{1}{|c|}{ Waste Item(s) Originally at Site } & \multicolumn{1}{c|}{ Apparent Waste Type* $^{*}$} \\
\hline Battery, Tank, Cistern & Recyclable \& Ordinary \\
\hline
\end{tabular}

* Ordinary, Scrap Metal, Asbestos, PCB, Salvageable, Hazardous, Radioactive, Mixed, Unlonown, Other

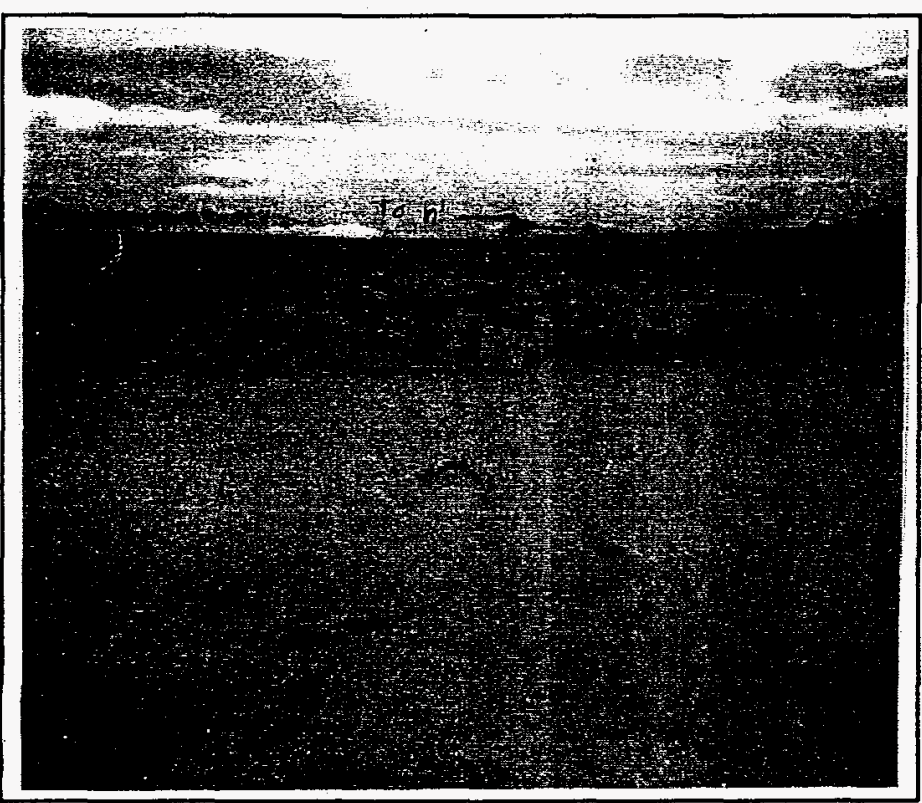

CAS Prior To Cleanup

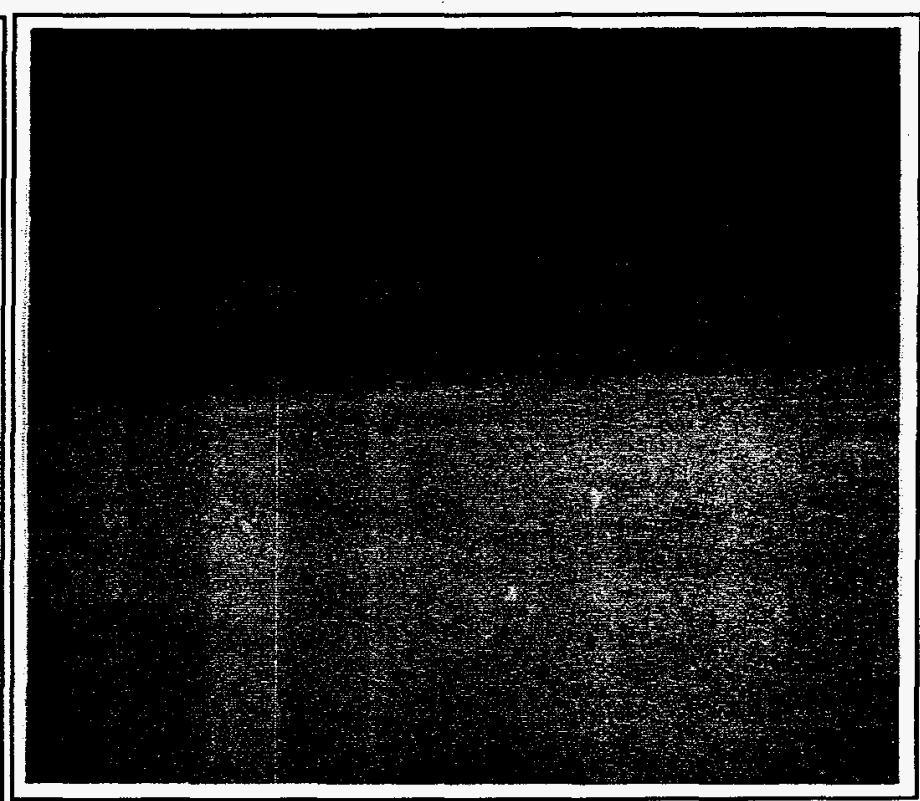

CAS After Cleanup

Current Site Description/Observations: Originally identified on 29-JAN-91, the CAS lies east of a posted Contaminated Waste Dump (CWD). Recovered debris consisted of the following: steel pipe sections, carbon batteries, intact lead acid batteries and battery plates, several lead bricks and sheets, broken glass, cable debris, metal debris, cement debris, empty propane tanks, and wood. NTS personnel conducted clean-up operations 08-AUG-97, 07-SEP-97, and 12-SEP-97. All solid waste was disposed at the Area 23 Landfill, batteries and plates were recycled through Fleet Operations, and lead materials were recycled through Property and Supply.

No Further Action Required at Corrective Action Site

C. Carlos Gonzales

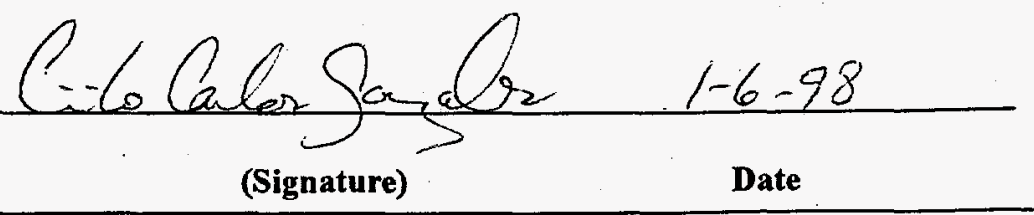




\section{FFACO CORRECTIVE ACTION SITE HOUSEKEEPING ClOSURE VERIFICATION FORM}

Closure Verification Date: 30-SEP-97

CAS Number: 05-99-06

General Location: GMX Facility

Latitude:

Longitude:

\author{
CAU Number: 347 \\ Elevation: \\ Northing: $764,269.567$ \\ Easting: $714,319.688$
}

Coordinate/Elevation Data Obtained from Garmen 40 Global Position System: Accuracy is within $300 \mathrm{ft}$ Horizontal - Vertical Varies with Locality

Site Access Route: North of Mercury on Mercury Hwy, veering north on the 5-01 Rd up to the road leading to the Sugar Bunker. Turn ight (east - opposite Sugar Bunker) on dirt road (P-Rd) for $0.4 \mathrm{mi}$. At intersection, turn left (N-NE) 0.65 mi towards wood shack. From wood shack, drive NE to GMX fence and follow in counter-clockwise direction approximately $0.3 \mathrm{mi}$ to CAS

\begin{tabular}{|l|l|}
\hline \multicolumn{1}{|c|}{ Waste Item(s) Originally at Site } & \multicolumn{1}{c|}{ Apparent Waste Type* $^{*}$} \\
\hline Decon Boots; Caustic Lime & Ordinary \\
\hline
\end{tabular}

* Ordinary, Scrap Metal, Asbestos, PCB, Salvageable, Hazardous, Radioactive, Mixed, Unknown, Other

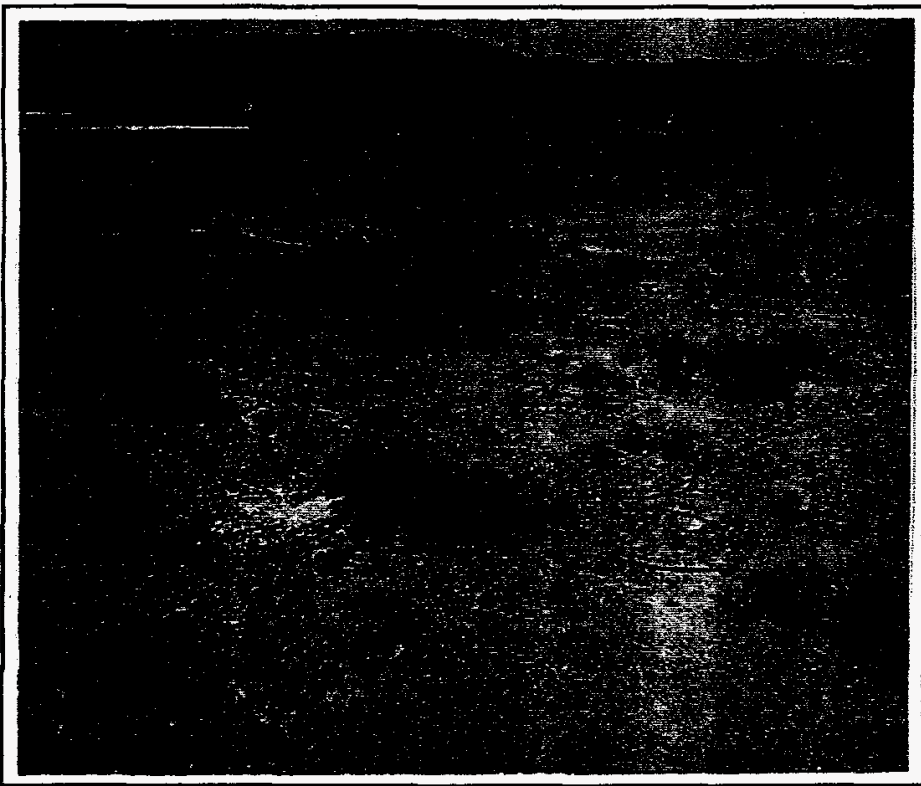

CAS Prior To Cleanup

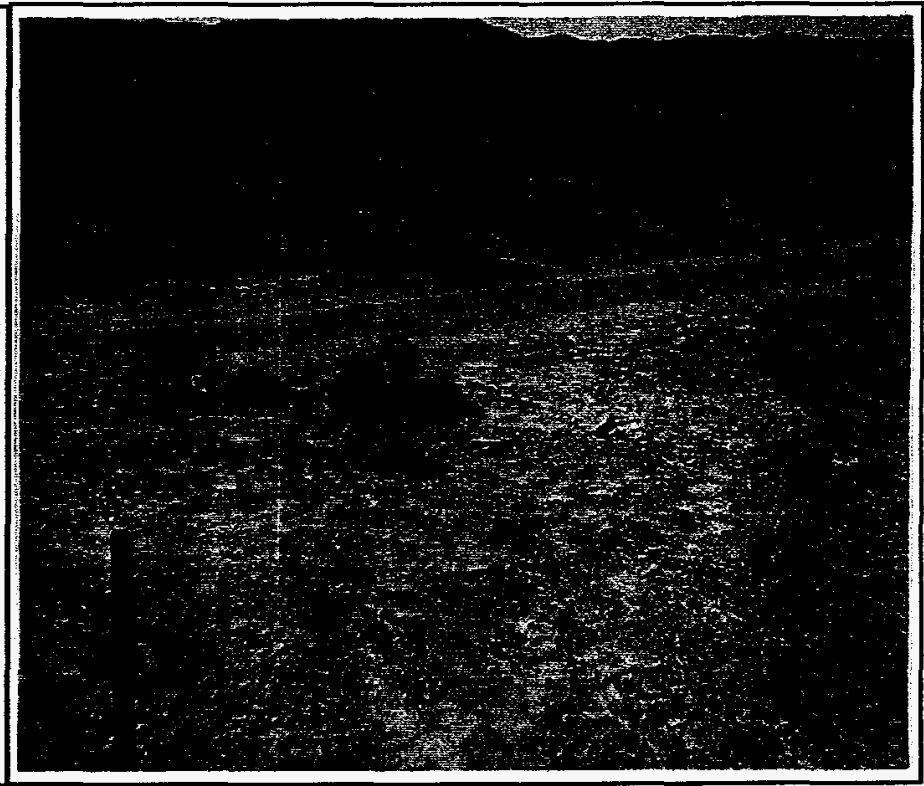

CAS After Cleanup

Current Site Description/Observations: Originally identified by NTS field crews on 26-AUG-93, the CAS was described as having debris between "two piles of lime." While NTS personnel were conducting clean-up operations, it was realized that the "lime" was actually smoke grenade and smoke pot product. The solid waste debris was disposed of at the Area 23 Landfill on 28-SEP-97, and the smoke pots were treated at the Area 11 Explosive Ordnance Disposal Unit on 30-SEP-97.

No Further Action Required at Corrective Action Site

C. Carlos Gonzales

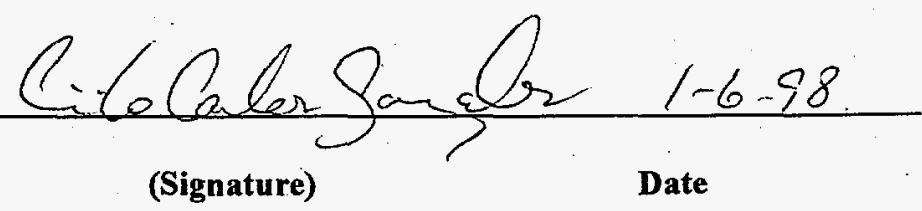

Corrective Action Coordinator/Designee

(Signature)

Date 


\section{FFACO CORRECTIVE ACTION Site HOUSEKEEPING CLOSURE VERIFICATION FORM}

Closure Verification Date: 28-APR-97

$\begin{array}{rlr}\text { CAS Number: } & 11-22-01 & \text { CAU Number: } 347 \\ \text { General Location: } & \text { Plutonium Valley } & \text { Elevation: } \\ \text { Latitude: } & 36^{\circ} 57^{\prime} 27^{\prime \prime} & \text { Northing: } \\ \text { Longitude: } & 115^{\circ} 58^{\prime} 03^{\prime \prime} & \text { Easting: }\end{array}$

Coordinate/Elevation Data Obtained from Garmen 40 Global Position System: Accuracy is within $300 \mathrm{ft} \mathrm{Horizontal} \mathrm{-} \mathrm{Vertical} \mathrm{Varies} \mathrm{with} \mathrm{Locality}$

Site Access Route: North of Mercury on Mercury Hwy, turning right (east) on Tweezer Rd. Turn right (south) on Orange Blossom Rd and follow to Rad-Safe Marker (RSM) 11A-20. Turn left (north) into Plutonium (Pu) Valley up to main intersection of dirt roads leading owards contaminated areas. The CAS is on the right (east) side of the main access road. An RCT escort and OCC pre-notification is required for entry into Pu Valley.

\begin{tabular}{|l|l|}
\hline \multicolumn{1}{|c|}{ Waste Item(s) Originally at Site } & \multicolumn{1}{c|}{ Apparent Waste Type* $^{*}$} \\
\hline (5) 55-Gal. Drums (empty) & Ordinary \\
\hline
\end{tabular}

- Ordinary, Scrap Metal, Asbestos, PCB, Salvageable, Hazardous, Radioactive, Mixed, Unknown, Other

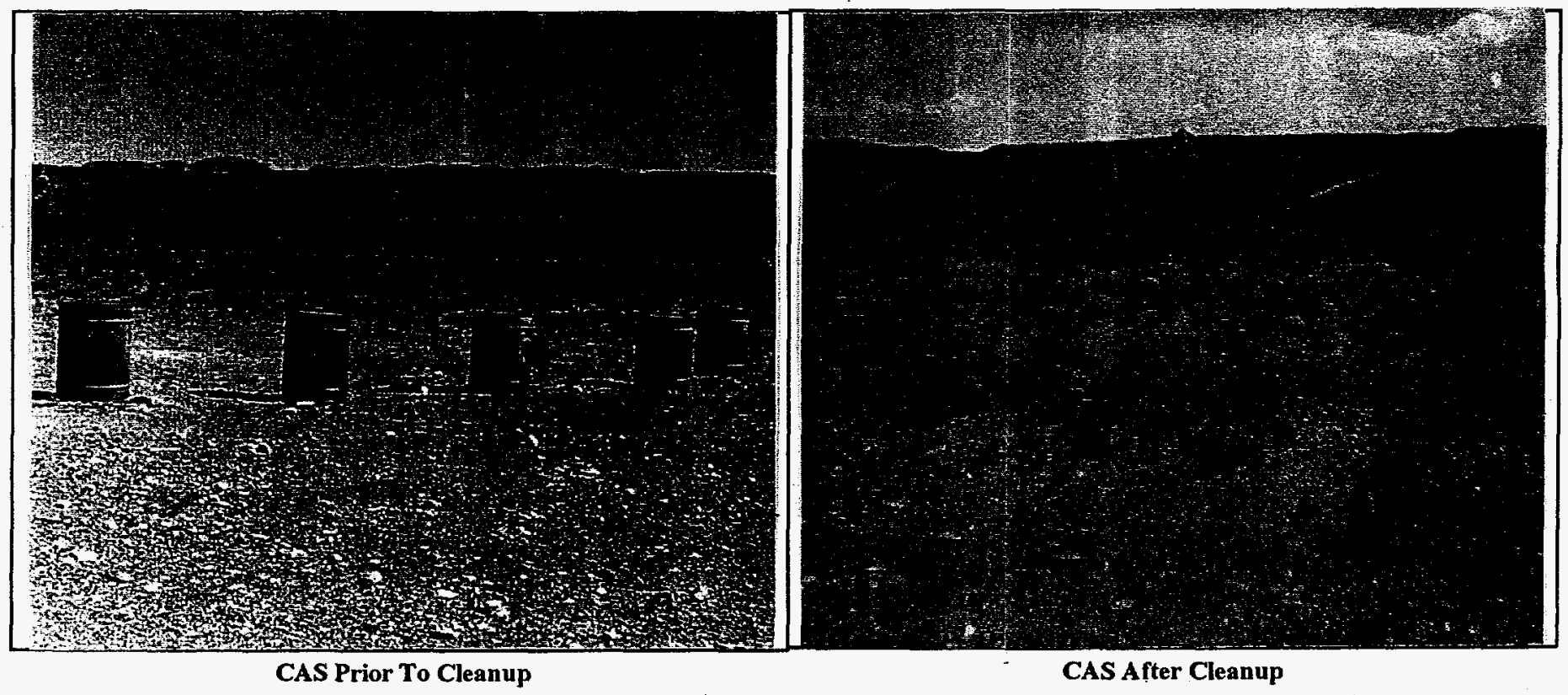

Current Site Description/Observations: Originally identified on 15-OCT-90, the CAS was verified to be clean on 28-APR-97 by NTS personnel. The drums at this CAS had previously been removed. Field files also contain a May 1992 memo to DOE/NV with a list of abandoned waste sites that had been cleaned; CAS 1 1-22-01 appears on the list. GPS coordinates were taken at the access road barricade by field crews on 23-APR-96.

No Further Action Required at Corrective Action Site

C. Carlos Gonzales

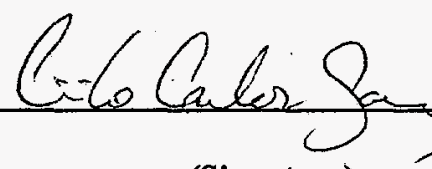

Corrective Action Coordinator/Designee

(Signature) $1-6-98$

Date 


\section{FFACO CORRECTIVE ACTION SITE HOUSEKEEPING ClOSURE VERIFICATION FORM}

Closure Verification Date: $28-A P R-97$

$\begin{array}{rlr}\text { CAS Number: } & 11-22-02 & \text { CAU Number: } 347 \\ \text { General Location: } & \text { Plutonium Valley } & \text { Elevation: } \\ \text { Latitude: } & 36^{\circ} 57^{\prime} 27^{\prime \prime} & \text { Northing: } \\ \text { Longitude: } & 115^{\circ} 58^{\prime} 03^{\prime \prime} & \text { Easting: }\end{array}$

Coordinate/Elevation Data Obtained from Garmen 40 Global Position System: Accuracy is within $300 \mathrm{ft}$ Horizontal - Vertical Varies with Locality

Site Access Route: North of Mercury on Mercury Hwy, turning right (east) on Tweezer Rd. Turn right (south) on Orange Blossom Rd and follow to Rad-Safe Marker (RSM) 11A-20. Turn left (north) into Plutonium (Pu) Valley up towards the $11 \mathrm{c}$ compound, location of aircraft ail section. The CAS is on the west side of fenced area (outside of contaminated zone). An RCT escort and OCC pre-notification is required for entry into Pu Valley.

\begin{tabular}{|l|l|}
\hline \multicolumn{1}{|c|}{ Waste Item(s) Originally at Site } & \multicolumn{1}{c|}{ Apparent Waste Type* $^{*}$} \\
\hline (6) 55-Gal. Drums (empty) & Ordinary \\
\hline
\end{tabular}

* Ordinary, Scrap Metal, Asbestos, PCB, Salvageable, Hazardous, Radioactive, Mixed, Unknown, Other

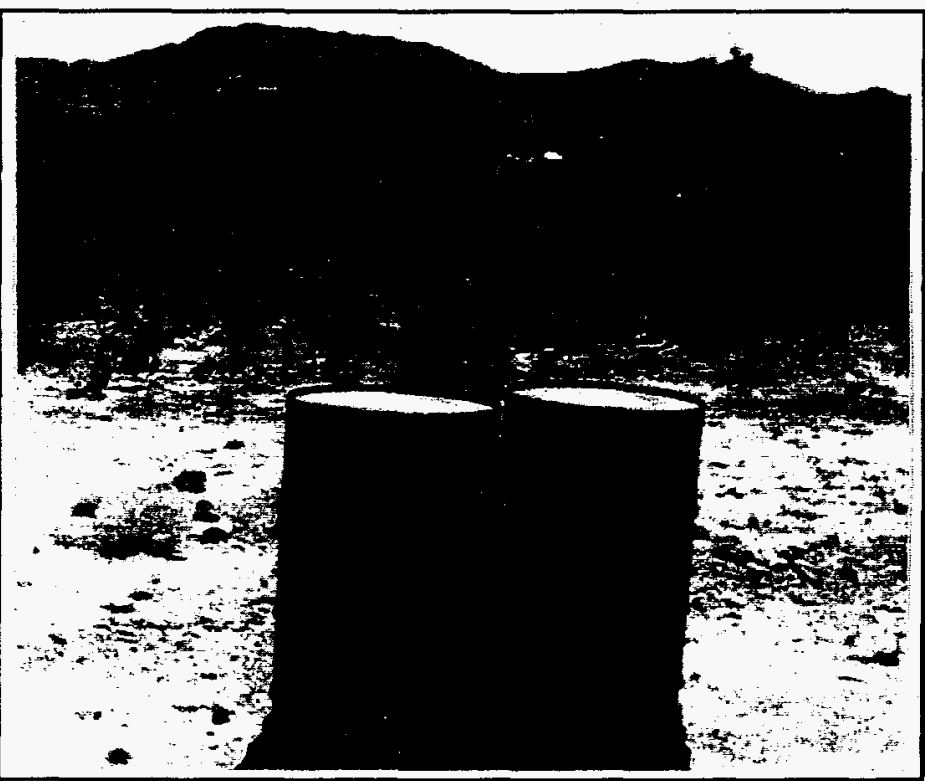

CAS Prior To Cleanup

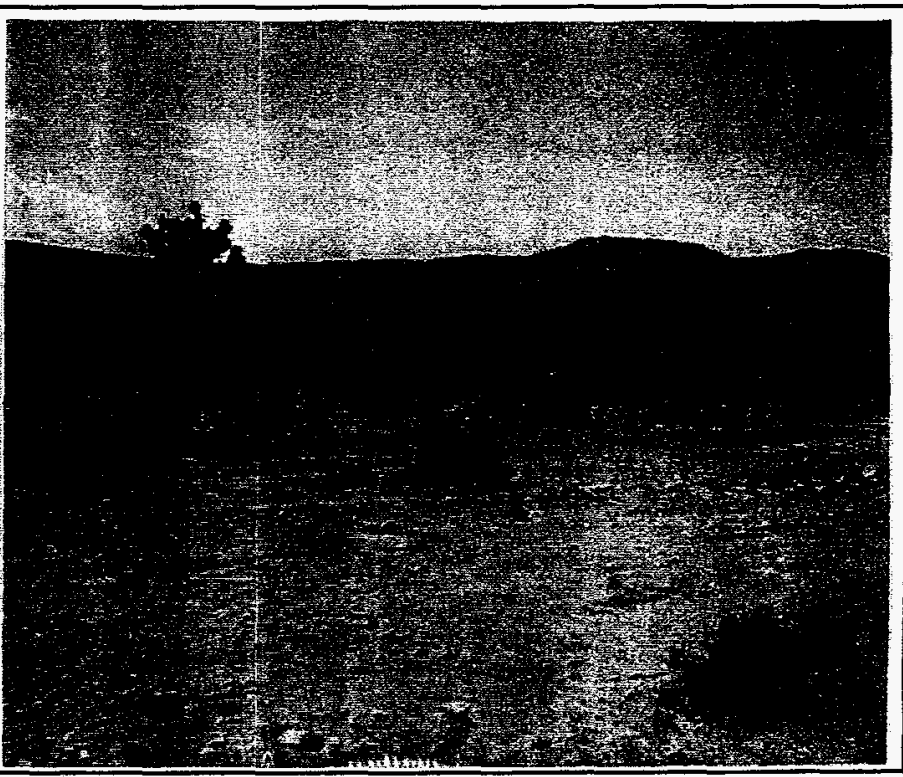

CAS After Cleanup

Current Site Description/Observations: Originally identified on 15-OCT-90, the CAS was verified to be clean on 28-APR-97 by NTS personnel. The drums at this CAS had previously been retrieved. Field files also contain a May 1992 memo to DOE/NV with a list of abandoned waste sites that had been cleaned; CAS 11-22-02 appears on the list. GPS coordinates were taken at the access road barricade by field crews on 23-APR-96.

No Further Action Required at Corrective Action Site

C. Carlos Gonzales

Corrective Action Coordinator/Designee
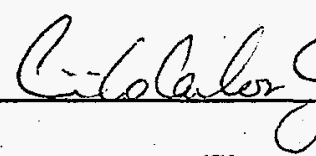

(Signature) $1-6-98$

Date 


\title{
FFACO CORRECTIVE ACTION SITE HoUSEKEEPING ClOSURE VERIFICATION FoRM
}

Closure Verification Date: $07-$ SEP-97

CAS Number: 11-22-09

General Location: Tweezer Facility

\author{
CAU Number: 347 \\ Elevation: \\ Northing: $801,005.054$ \\ Easting: $\quad 707,226.343$
}

Latitude:

Longitude:

Coordinate/Elevation Data Obtained from Garmen 40 Global Position System: Accuracy is within 300 ft Horizontal - Vertical Varies with Locality

Site Access Route: North of Mercury on Mercury Hwy, turn right (east) on Tweezer Rd. Turn right (south) on Orange Blossom Rd and follow to Tweezer Facilities. Drive 0.5 mi past Rad-Safe Marker (RSM) 11A-22 to rear of facilities. The CAS is identified with a marker, ppproximately 20 yards west of two large silver tanks.

\begin{tabular}{|l|l|}
\hline \multicolumn{1}{|c|}{ Waste Item(s) Originally at Site } & \multicolumn{1}{c|}{ Apparent Waste Type* $^{*}$} \\
\hline (1) Drum & Unknown \\
\hline
\end{tabular}

* Ordinary, Scrap Metal, Asbestos, PCB, Salvageable, Hazardous, Radioactive, Mixed, Unknown, Other

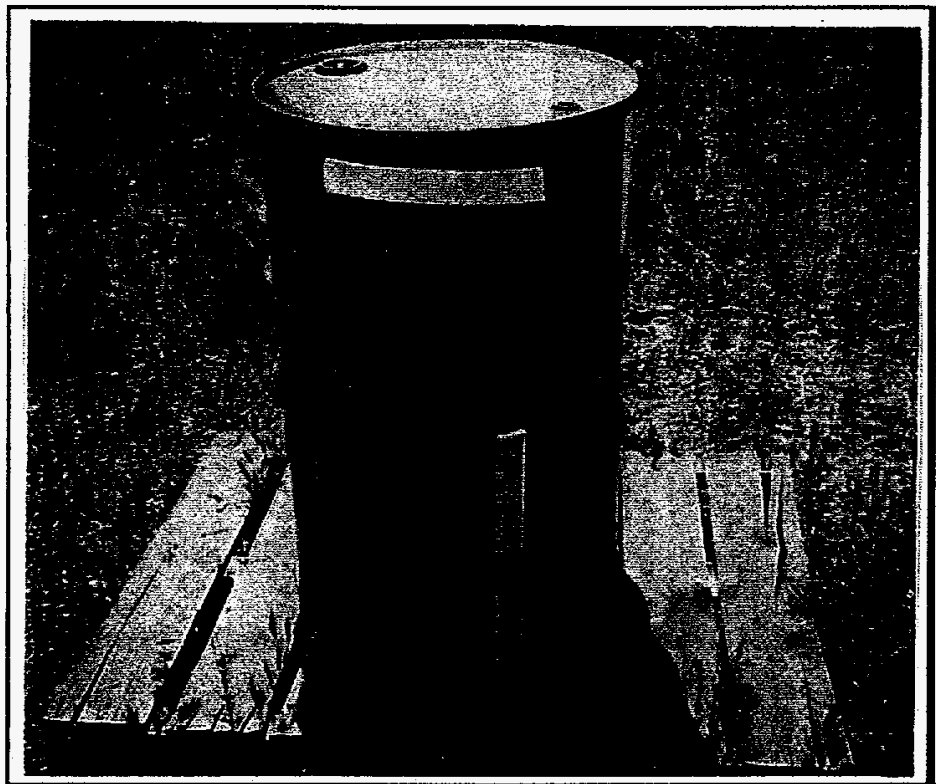

CAS Prior to Cleanup

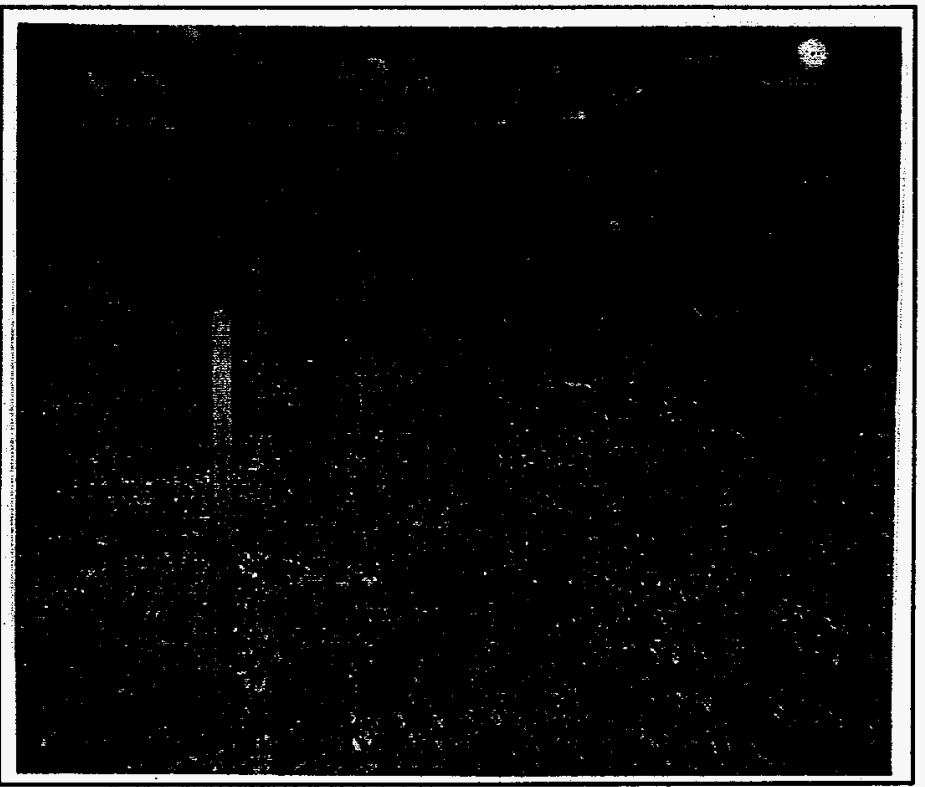

CAS After Cleanup

Current Site Description/Observations: Originally identified on 21-JAN-94, the drum was labeled "sodium methyl silanolate." According to BN Ecological Services, the drum actually contained a product called "R-8376 Surfactant" used by Nevada Dust Control. The area south of the Tweezer compound was an active ecological study plot, with the product stored outside the fenced study area. Additional drums, stored inside the fenced area, also contained the soil surfactant. All containers were found to be empty when cleanup operations were initiated at the CAS. In addition to the containers, the equivalent of two roll-off boxes of debris were retrieved for disposal at the Area 9 U10c Landfill.

No Further Action Required at Corrective Action Site

C. Carlos Gonzales

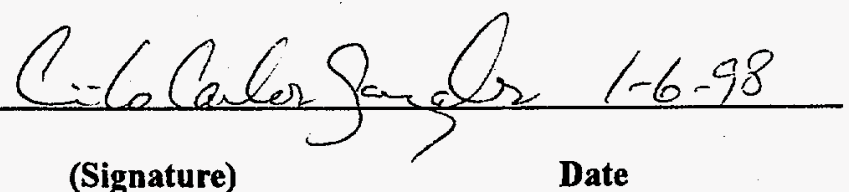




\section{FFACO CORRECTIVE ACTION SITE HOUSEKEEPING CLOSURE VERIFICATION FORM}

Closure Verification Date: $19-$ SEP-97

$\begin{array}{rlr}\text { CAS Number: } & 11-24-01 & \text { CAU Number: } \\ \text { General Location: } & \text { Plutonium Valley } & \text { Elevation: } \\ \text { Latitude: } & 36^{\circ} 57^{\prime} 27^{\prime \prime} & \text { Northing: } \\ \text { Longitude: } & 115^{\circ} 58^{\prime} 03^{\prime \prime} & \text { Easting: }\end{array}$

Coordinate/Elevation Data Obtained from Garmen 40 Global Position System: Accuracy is within $300 \mathrm{ft}$ Horizontal - Vertical Varies with Locality

Site Access Route: North of Mercury on Mercury Hwy, turning right (east) on Tweezer Rd. Turn right (south) on Orange Blossom Rd and follow to Rad-Safe Marker (RSM) 11A-20. Turn left (north) into Plutonium (Pu) Valley. The CAS is located $0.5 \mathrm{mi}$ SW of the Pu Valley Rd and wash junction, and rests on a small, cement pillar on the slope facing the wash. An RCT escort and OCC pre-notification is required for entry into Pu Valley.

\begin{tabular}{|l|l|}
\hline \multicolumn{1}{|c|}{ Waste Item(s) Originally at Site } & \multicolumn{1}{c|}{ Apparent Waste Type* } \\
\hline Batteries & Ordinary (Dry Cell-Type) \\
\hline
\end{tabular}

* Ordinary, Scrap Metal, Asbestos, PCB, Salvageable, Hazardous, Radioactive, Mixed, Unlonown, Other

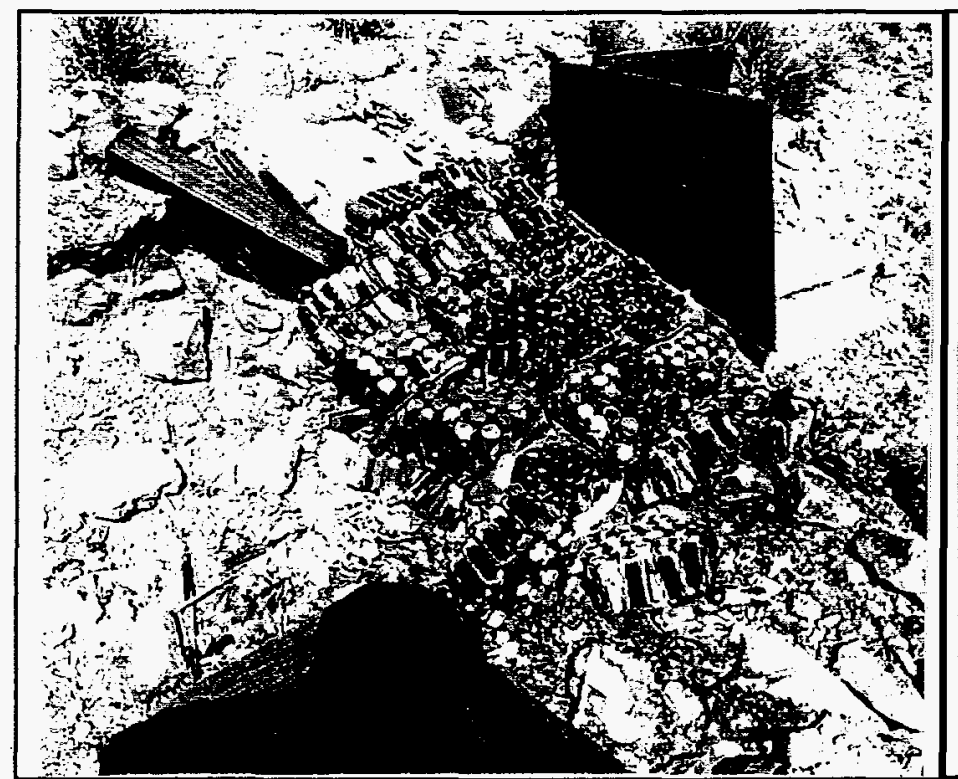

CAS Prior To Cleanup

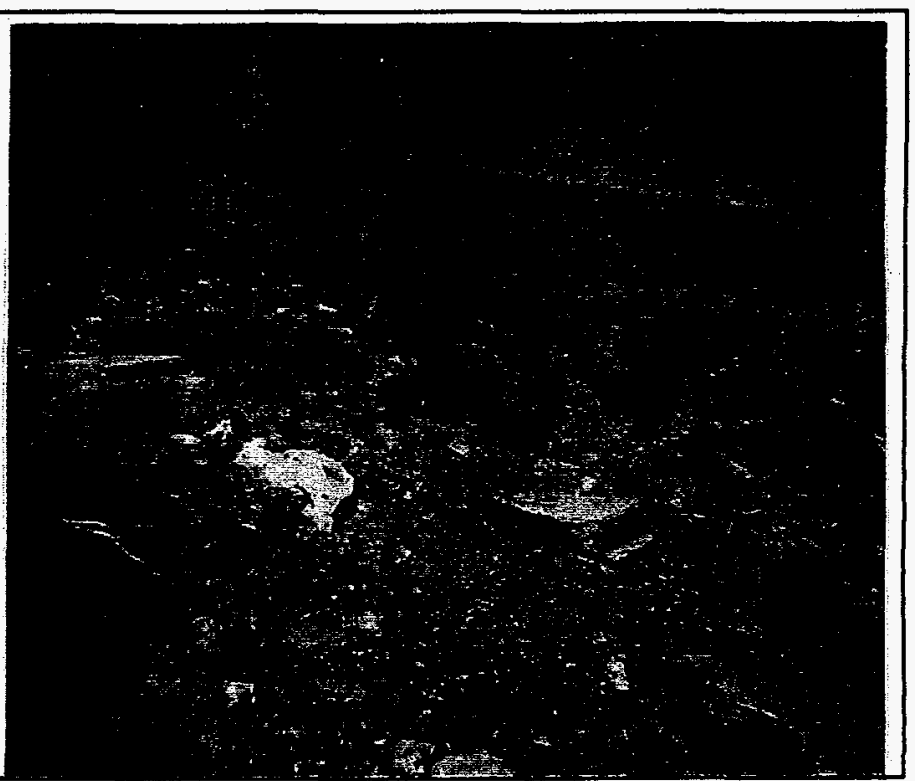

CAS After Cleanup

Current Site Description/Observations: Originally identified on 20-FEB-91, the waste of concern consisted of 32 broken dry cell battery packs. Field files contain a January 1992 in-house memorandum indicating that the batteries had been removed from this site and properly dispositioned. NTS personnel verified that the batteries were no longer present at the CAS. Wood debris remaining at this location was retrieved and disposed of at the Area 23 Landfill.

No Further Action Required at Corrective Action Site

C. Carlos Gonzales

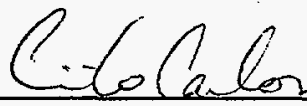

(Signature)

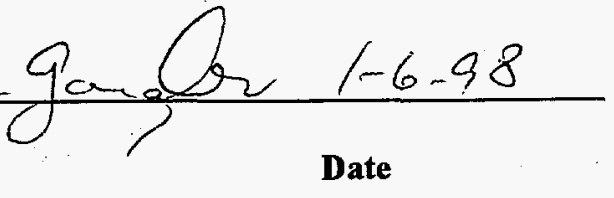


U. S. Department of Energy, Nevada Operations Office

P. O. Box 98518

Las Vegas, NV 89193-8518

J. L. Appenzeller-Wing

Public Reading Room

Technical Information Resource Center

U. S. Department of Energy,

Office of Scientific and Technical Information

175 Oak Ridge Turnpike

P. O. Box 62

Oak Ridge, TN 37831

Bechtel Nevada

P. O. Box 98521

Las Vegas, NV 89193-8521

D. K. Cowser

J. R. Kannard

C. C. Gonzales

\section{IT Corporation}

4330 South Valley View, Suite 114

Las Vegas, NV 89103-4047

R. C. Silver 